\title{
REGULATIONS IN PLANNING \\ UNDERSTANDING THE RELATIONSHIP OF THE GROWTH PLAN FOR THE GREATER GOLDEN HORSESHOE AND HOUSING AFFORDABILITY
}

\author{
by \\ Benjamin Pister \\ B.Sc. (Honours), McMaster University, 2015 \\ A Major Research Paper \\ presented to Ryerson University \\ in partial fulfillment of the requirements for the degree of \\ Master of Planning \\ in \\ Urban Development
}

Toronto, Ontario, Canada, 2017

(C) Benjamin Pister, 2017 
I hereby declare that I am the sole author of this MRP. This is a true copy of the MRP, including any required final revisions, as accepted by my examiners.

I authorize Ryerson University to lend this MRP to other institutions or individuals for the purpose of scholarly research

I further authorize Ryerson University to reproduce this MRP by photocopying or by other means, in total or in part, at the request of other institutions or individuals for the purpose of scholarly research.

I understand that my MRP may be made electronically available to the public. 


\title{
REGULATIONS IN PLANNING \\ UNDERSTANDING THE RELATIONSHIP OF THE GROWTH PLAN FOR THE GREATER GOLDEN HORSESHOE AND HOUSING AFFORDABILITY
}

\author{
(C) Benjamin Pister, 2017 \\ Master of Planning \\ in \\ Urban Development \\ Ryerson University
}

\begin{abstract}
This research paper explores what impacts regional regulation, and the resulting planning process, has on ground-related housing. The Growth Plan for the Greater Golden Horseshoe

(Growth Plan) is a significant regulation requiring evaluation. It has been suggested that density targets mandated by the Growth Plan have continuously decreased the supply of ground-related housing in the Greater Golden Horseshoe (GGH). The combination of regional regulations and the time of processing development applications play an important role in understanding changes in housing supply. A case study of York Region displayed this concept, such that the requirements of the Province, and the resulting changes to the planning system for the Region, has contributed to decreases in supply of ground-related housing. Prices continue to rise due to increasing demand for the housing type. This research suggests four recommendations for the Proposed Growth Plan to increase the inventory of ground-related housing: 1) reducing density targets, 2) realigning the planning process to reduce time lag, 3) observing market demand, and 4) removing a one-size-fits-all policy which currently exists within the Growth Plan.
\end{abstract}

Key Words: affordability, density, housing, regional, regulation 


\section{Acknowledgements}

I would first like to thank my supervisor, Prof. David Amborski, for his endless support while completing this research. His vast knowledge of land development and affordability issues in the Greater Toronto Area were key to forming my major research paper. Second, I would like to thank Dr. Frank Clayton for being my second reader. He provided me with a great insight on land supply issues in the Greater Golden Horseshoe. Also, his strong research background allowed me to efficiently and effectively place my thoughts on paper.

I also want to thank all my classmates. We made it! It wasn't an easy two years, but we worked hard to where we are now. I had the opportunity to work with each of you in some way, whether in small group projects, studios, or just to chat about our research. We've molded ourselves into one strong group of urban planning graduates. I can say without a doubt, each and every one of us has a bright future ahead, and I cannot wait for our paths to cross in future projects!

Finally, I dedicate this paper to my fiancée, Devora, who continuously supports me while I develop my professional career and live my dream. This research paper would not have been completed without the constant inspiration you give me day after day. 


\section{Table of Contents}

CHAPTER 1 INTRODUCTION 1

$\begin{array}{ll}\text { 1.1 The Objective } & 2\end{array}$

1.2 Justification - The Mayors and Chairs Summit Report 3

$\begin{array}{lc}\text { 1.3 Methods for Research } & 4\end{array}$

CHAPTER 2: LITERATURE REVIEW

2.1 What can be Defined as Excessive Regulation and Its Implications for Housing? $\quad 7$

2.1.1 Measuring the Impacts of Land Use Regulation $\quad 10$

2.2 Urban Containment in the GGH and the Implementation of the Growth Plan 14

2.2.1 The Fraser Institute $\quad 15$

2.2.2 Opposing Side of the Argument - RBC and Pembina Institute Report 16

2.2.3 Malone Given Parsons Ltd. Report \& CUR Housing Supply Event 17

2.3 Preliminary Applications to Regulation and Housing Costs 20

2.3.1 Glaeser, Gyourko, \& Saks Manhattan Study - Construction-Purchase Price Gap 20

2.3.2 Applying the Wharton and Fraser Indexes 21

2.3.3 Case Study: Washington DC 22

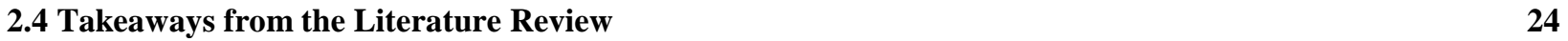

CHAPTER 3 YORK REGION: A CASE STUDY 26

$\begin{array}{lr}\text { 3.1 York Region Housing Data } & 28\end{array}$

$\begin{array}{lc}\text { 3.2 Changes in Median Income } & 31\end{array}$

3.3 Changes in the Supply of Land $\quad 31$

3.4 Master Plans and the Official Plan $\quad 33$

3.4.1 The Water and Wastewater Master Plan 34

3.4.2 Transportation Master Plan (TMP) 36

3.4.3 York Region's Regional Official Plan 38

3.5 York Region's Response to the Proposed Density Requirements 40

CHAPTER 4 RESPONSE FROM DEVELOPERS 42

4.1 The Project Approval Timeline 42

4.2 High Density and Zoning Changes 43

CHAPTER 5 CONCLUSION AND NEXT STEPS 45 


\subsection{Next Steps}

5.1.1 Reduce the target of 80 People and Jobs per hectare in Designated Greenfield Areas 47

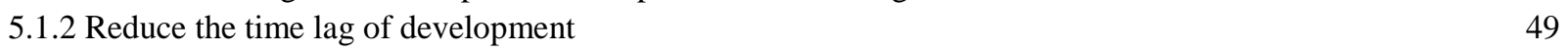

$\begin{array}{ll}5.1 .3 \text { Watch market demand } & 50\end{array}$

5.1.4 Transition to Remove a One-Size-Fits-All Policy

$\begin{array}{ll}\text { APPENDICES } & 56\end{array}$

$\begin{array}{lc}\text { REFERENCES } & 65\end{array}$

\section{List of Figures}

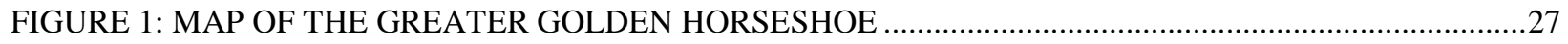

FIGURE 2: NUMBER OF HOUSING STARTS IN YORK REGION ..........................................................2

FIGURE 3: AVERAGE COST OF CONSTRUCTION IN THE GREATER TORONTO AREA............................29

FIGURE 4: REQUIRED IMPROVEMENTS FOR WATER AND WASTEWATER …..........................................36

FIGURE 5 YORK REGION INTENSIFICATION TARGETS FROM 2006-2031 ................................................39

FIGURE 6: DESIGNATED GREENFIELD AREAS FOR MARKHAM ……...................................................49

FIGURE 7: UPPER TIER MUNICIPALITIES MEETING INTENSIFICATION TARGETS ................................53

\section{List of Tables}

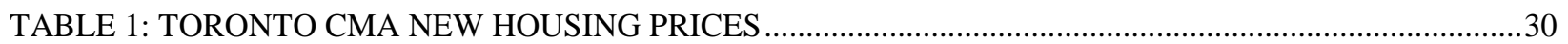

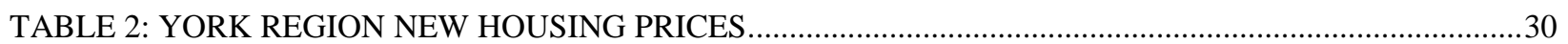

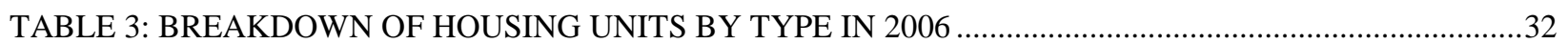

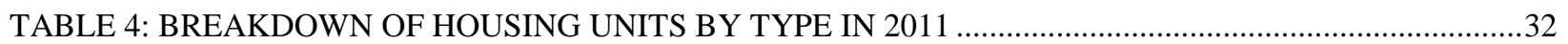

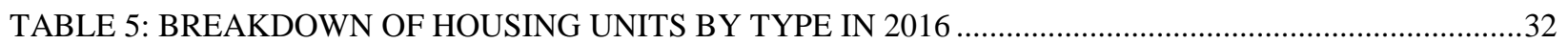

\section{List of Appendices}

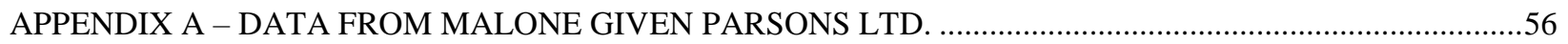

APPENDIX B - ALTUS CONSTRUCTION COSTS TABLE (FROM 2006-2016) …….......................................57

APPENDIX C - SCHEDULE OF WATER AND WASTEWATER SERVICING IMPROVEMENTS ....................58

APPENDIX D -YORK REGION WATER \& WASTEWATER SERVICING MAPS …......................................60

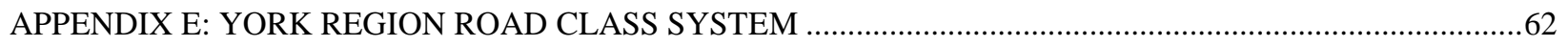

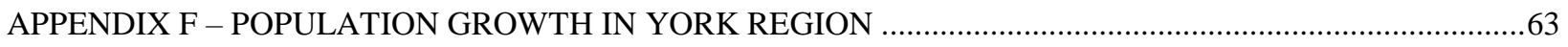

APPENDIX G - MAP OF YORK REGION, INCLUDING ROPAS 1, 2 \& 3 ....................................................64 


\section{Chapter 1 Introduction}

The housing market today is a major issue in the Greater Toronto Area (GTA). Market prices have risen significantly for ground-related housing, such as single-detached houses, semidetached houses and row/townhouses ${ }^{1}$. Since 2006, new housing prices have had high year-overyear changes, much higher than the annual rate of inflation. For example, the year-over-year change of new housing prices in 2015 was 16\% (CMHC, 2017). This high rate of change in prices has been demonstrated to be related to the tight supply of housing ${ }^{2}$. As housing prices continue rising, families are looking outside the GTA for affordable places to live, such as Barrie, Brantford, Hamilton, Guelph, and St. Catharines ${ }^{3}$. This trend is causing spillover effects of rising prices to other census metropolitan areas in the GGH. For example, housing prices in Hamilton are changing by a factor of 1.4 times the change of housing prices in the GTA (Michel, 2017). What factors have been causing this significant upswing in prices?

The Growth Plan for the Greater Golden Horseshoe (2006) is a policy by the Government of Ontario outlining a direction for growth within the Greater Golden Horseshoe (GGH). The 2006 Growth Plan takes into consideration previous implemented land conservation policies, such as the Greenbelt Plan (2005), the Niagara Escarpment Plan (2005), and the Oak Ridges Moraine Conservation Plan (2002). The purpose of the Growth Plan is to guide municipalities in the GGH, specifically how and where development should occur (i.e. intensification or greenfield ${ }^{4}$ ) to meet

\footnotetext{
${ }^{1}$ While looking at data provided by the Canada Mortgage and Housing Corporation, it was noticed that prices have risen significantly for both newly constructed ground-related housing as well as the existing housing stock.

2 Tight supply refers to the failure of ground-related housing supply to respond quickly to rising demand, in other words an inelastic supply.

${ }^{3}$ Municipalities that are within reasonable commuting distance of the Greater Toronto Area (Michel, 2017)

${ }^{4}$ Intensification implies increasing the density for an area previously developed, while greenfield development implies constructing on undeveloped land
} 
specific population and employment densities. Within the 2006 Growth Plan, there are policies outlining minimum density requirements for development, specifically 50 people and jobs per hectare in designated greenfield areas, and $40 \%$ of all residential development in a municipality must be done through intensification (i.e. infill development). In mid-2016, the Ontario Government released a proposed updated Growth Plan. If approved, the new minimum density targets would be 80 people and jobs per hectare in designated greenfield land and $60 \%$ of growth through intensification (Government of Ontario, 2016). The Province's intension is to create improvements in reducing negative environmental impacts and congestion issues, yet the Growth Plan has had a negative impact on the supply of ground-related housing and overall housing affordability.

In relationship with planning regulation, reports have suggested the mandated Growth Plan has had a significant contribution to the quick rise of housing prices. Both academic and professional organizations have suggested a cause and effect relationship between highly regulated policies at the regional level and housing prices. These sources include Malone Given Parsons LTD. (2015), Ryerson Unversity's Centre for Urban Research and Land Development (2016), and the Fraser Institute (2016).

\subsection{The Objective}

The purpose of this research paper is to gain an understanding of the connections between the planning process and housing supply, mainly what pieces of the planning process are having significant impacts on the supply of ground-related housing. The primary goal is to outline recommendations on improving the Proposed Growth Plan to better inform planning processes of upper tier and single tier municipalities, and leading to increases in supply of ground-related 
housing. Enabling the GGH to meet rising homeowner demand can help mitigate issues of housing affordability. This research paper will be completed though a 3-stage narrative:

1) Discussing previous research comparing regulation with housing supply and affordability;

2) Forming a case study with York Region by understanding its planning situation; and

3) Providing a framework of recommendations to include in the revised Proposed Growth Plan;

to include housing affordability improvements as a means to sustainable regional growth.

\subsection{Justification - The Mayors and Chairs Summit}

In a recent report by the Mayors and Chairs Summit (2016), there was much dismay in regard to the proposed densities, especially since these density targets are uniform throughout the GGH (i.e. one-size-fits-all). Attendees ${ }^{5}$ which included mayors, chairs, city officials, and developers from the GGH (including York Region), brought up concerns about the great need for improved infrastructure throughout the region in order to build-out the proposed densities. For example, attendees were concerned about the lack of available public transit to many of the municipalities within the GGH. The Report also commented on the issue of time lags between submission of a development application to receiving site plan or plan of subdivision approval. This time lag is playing a role in delaying the much needed supply of ground-related housing. The proposal to reach much higher density targets creates a concern that less housing choices will be made available to middle and lower income classes. This is due to the fact that in order to meet density requirements, municipalities will have to build a greater inventory of smaller units, limiting future housing options to mostly apartment-style units. The requirement of these

\footnotetext{
${ }^{5}$ Including Mayors from lower tier municipalities within the Regional Municipalities of, Durham, Halton, Peel, and York; Chief Planners and CAOs from the Regional Municipalities of Durham, Halton, Peel, \& York, and the City of Hamilton.
} 
proposed densities applies to a municipality in its entirety. Although a municipality may achieve the minimum density targets, it would require a very significant dense buildout due to designated conservation lands ${ }^{6}$, cemeteries, parklands, employment lands, etc. Although these lands are already designated for other purposes, they are still included in overall density requirements. The Summit Report brings up important concerns of regulation, and questions the extent we can impose political land constraints and regulations on municipalities, especially a one-size-fits-all policy (McCallion, 2016).

The tools found in previous research can help inform the influences land use regulations \& the planning process have with housing supply. This will be useful in quantifying and measuring current regulation as well as future land use policies. The Ministry of Municipal Affairs and Housing is taking into consideration "all submissions and comments received... (to) modify the Proposed Growth Plan for the Greater Golden Horseshoe" (Government of Ontario, 2016). This is an ideal opportunity to inform the government that an economic evaluation tool is necessary in order to plan our municipalities for the long term - and improve housing supply through adjustments of the Growth Plan.

\subsection{Methods for Research}

Literature Review: For this research paper, the literature explored covers studies understanding the connection between land-use regulations and housing supply and affordability. This review also includes reports completed on measuring land-use regulation in Canada, and completed evaluations of the Growth Plan.

\footnotetext{
${ }^{6}$ Specifically, policies directed to the Greenbelt, Oak Ridges Moraine, and Niagara Escarpment
} 
Case Study on York Region: In order to gain a more direct understanding on the implications of the Growth Plan on the overall planning process, a case study was completed reviewing changes of development in York Region. The case study is divided into two sections: The first discusses what has changed in the last 10 years, since the Growth Plan was mandated. The second section describes York Region's ability to supply ground-related housing. We will find that York Region has a plan to 2041 based on the 2006 Growth Plan, yet the Proposed Growth Plan will have significant implications on that plan.

To understand changes in the last 10 years, the research looks at changes in: 1) housing starts in York Region, 2) construction costs in the GTA by Altus, and 3) new housing prices in York Region by CMHC; all since 2006. Average price changes for the GTA were also collected as a comparative benchmark to York Region. To understand York Region's ability to supply ground-related housing a review was completed on the Water $\mathcal{E}$ Wastewater Master Plan, the Transportation Master Plan, and the Official Plan. These plans are required to conform to the Growth Plan.

Interviews: These were conducted with stakeholders of development in York Region. Consultation was done with both 2 municipal staff and 3 developers to help with understanding the current situation in developing York Region. The discussions with municipal staff led to choosing crucial documents ${ }^{7}$ to review for this research. The interviews with developers helped inform the changes in the planning process in York Region. Specific questions were asked to help lead these discussions, and were informed by the literature review. Examples of such questions

\footnotetext{
${ }^{7}$ Planning and policy documents related to the development and future growth of the Regional Municipality of York
} 
were: What is the range of time between submitting a development application and receiving a plan of subdivision approval or a building permit? Where are the greatest cost burdens for development? What areas of York Region are becoming more difficult to develop? What implications might the Proposed Growth Plan have on development? 


\section{Chapter 2: Literature Review}

This chapter provides the reader with a background on the connections between land-use regulation and ground-related housing supply. Understanding accepted definitions of overregulation is important for this research. There are various methods to measure excessive regulation that can potentially apply to regional regulations such as the Growth Plan. The review also guided the research's style and content of questions to both developers and municipal staff. The literature review is broken down into four sections:

Section 1 defines land-use regulation, and describes past research on the concept of excessive regulation and the implications on housing development. The goal here is to understand ways of measuring regulation using cost-benefits analysis, and various regulation indexes.

Section 2 provides a discussion on urban growth containment policy and a description of the Growth Plan, which is a growth containment policy.

Section 3 summarizes completed research on the Growth Plan - in terms of its relationship with housing supply and costs. There is a greater focus on data related to the 2006 Growth Plan, due to the limited available data pertaining to the Proposed Growth Plan.

Section 4 describes the takeaways from the review, and helps to inform the remainder of this paper.

\subsection{What can be Defined as Excessive Regulation and Its Implications for Housing?}

"The performance of regional economies will be improved thanks to efficient urbanization" (Kim, 2011, 36). Forms of urban containment can assist with improving overall productivity and liveability. Living within a more compact urban form has the potential to 
improve agglomeration economies and efficiencies for businesses. Urban containment advocates to curb negative externalities such as distance of travel, congestion, and overall environmental damages. At the same time, the extent of regional government intervention through land use regulations can actually have negative impacts (Luger \& Temkin, 2000). For instance, regulations placed on a metropolitan region could prevent local municipalities and private sectors from providing the minimum goods based on demands of their residents (J. H. Kim, 2011). Looking at the Proposed Growth Plan, the province has outlined general density requirements for the GGH. While the City of Toronto can maintain these densities due to its long history of intensification, more recently developed municipalities within the GGH are struggling to meet those same density values. Furthermore, in order to achieve the density targets a greater proportion of apartment units are required, yet municipalities are finding it difficult to provide the necessary infrastructure improvements (i.e. servicing) to permit increased density building. Furthermore, the increase in apartment units and the inelastic ${ }^{8}$ supply of ground-related housing does not meet the unit-type demand by potential homeowners. Whether or not municipalities can achieve these density targets, are the new density requirements too high to ask for? In relationship to the tight supply of ground-related housing, is it due to the Proposed Growth Plan forming exaggerated density targets?

While a change in the elasticity of supply has an impact on prices, there can be additional costs downloaded to the potential buyer influenced by land use regulations. Such regulations include zoning designations, environmental restrictions, and financial impacts. In most cases,

\footnotetext{
${ }^{8}$ Elasticity refers to the flexibility of a variable to change with another variable. Inelastic supply suggests that although demand for a specific housing type is increasing, there is limited response from the variable of supply.
} 
development itself will be delayed in order to conform to new or amended regulations. Also, the number of people involved with each stage of a development application overall impedes on development. Time delay in the planning process is impactful on developing permitted housing. The perception is that the time from "purchasing raw land to acquiring approval for any zoning reclassification through site plan development and securing permits..." will have impacts on the costs of the stock provided (Luger \& Temkin, 2000). Geographic constraints (e.g. bodies of water, areas of poor shear strength soils) along with political constraints are major factors in contributing to rising costs in housing due to the tightening of supply. This was found in the United States by Huang (2012) while studying roughly 300 cities from 1980 until 2008. During a housing boom, prices increased more in cities with higher geographic and political constraints, versus in cities with few constraints. In general, a housing bust should cause housing costs to drop significantly if the prices rise well above the marginal construction cost of units. However, the high levels of constraints on supply has the potential to cause only a minimal decrease in housing prices if the demand remains unchanged. In the context of the United States, large price drops for housing in constrained cities were found when loan rejections were low (Huang, 2012). This may suggest that for the GGH, an actual major price correction would occur only if there is a major economic shift within the market. Alternative methods of slowing down or changing the ground-related housing market is necessary, and one such way is by amending or creating new regional regulations (New Zealand Productivity Commission, 2016). The next subsection provides ways of analyzing the extent of regulation and potential implications on development. 


\subsubsection{Measuring the Impacts of Land Use Regulation}

Completed research has provided ways to understand the extent regulation has on development; two of which are (1) cost-benefit analyses ${ }^{9}$ and (2) regulation measurement indexes. In many cases, regulations and associated costs can become unnecessary - leading to missed steps in the development process, or unclear regulation requirements (Luger \& Temkin, 2000).

Malpezzi \& Bertaud - Cost-Benefit Analysis

A study completed by Malpezzi \& Bertaud (2001), tried to explain pros and cons of a one-sizefits-all-type policy. They explain that the method of imposing a land use regulation will imply whether its respective costs outweigh its benefits, or vise-versa. There are two basic methods to land use regulation and how they relate to cost-benefit. The scenario provided is as follows: A builder invests in a parcel of land for development. A policy by the local municipality requires the developer to pay for roads in order to make the development properly accessible. There are two methods offered:

1) If the developer devotes too little land for roads, then this can actually lead to a market failure (i.e. congestion). To prevent this, a governing body will step in with a site-specific policy that enforces how much land is required to designate for roads. In this method, policies are created on a case-by-case basis and the cost-benefit becomes relatively equal as you are considering the needs of the municipality and the developer.

\footnotetext{
${ }^{9}$ A process that considers alternatives to a problem, to find a solution that provides the most benefits - or benefits that outweigh costs.
} 
2) An alternative approach to a case-by-case policy is the Second Best Cost-Benefit Model. In this method, the governing body makes more general approximations and boundaries. The costs are more generally defined and there are potential general benefits to the region. Problems begin to arise with the latter method, such that costs may very well outweigh the benefits. In the case of road requirements - due to the generalization of the regulation, it can lead to surplus land designated for roads. For example, the regulation requires the developer to build a road with a 7 -metre width at a cost of $10 \$$ per square foot. In reality the road only needs to be 5 metres wide, and so the oversupply of roads creates unnecessary extra costs for the developer. The developer is required to pay an extra cost for the roads that will not reach full potential from the community being built. For every additional regulation that is generalized (i.e. one-size-fitsall), the costs can more noticeably outweigh the benefits (Malpezzi \& Bertaud, 2001). The builder has their own minimum profit requirement, or specific rate of return from their investment, and therefore any additional development costs that are a burden to their return will be imposed on the buyer (Luger \& Temkin, 2000). This report was based on studying regulation patterns in Malaysia, where it was noticed that prices were becoming too burdensome on the home purchaser (Malpezzi \& Bertaud, 2001). We can apply a similar understanding for the Growth Plan, where the minimum density target for a municipality is too high to meet the market demand. The one-size-fits-all density can impose many costs on the local municipality whose density is far lower and does not have the infrastructure in place to allow for such density development (Regional Municipality of York, 2016). Can it be suggested that a uniform group of density requirements in-fact causes an imbalance in development costs for a municipality and developer? 
It should be mentioned that a specific designation for a parcel of land can also take away focus from the larger picture of consistent regional development. A balance of both (local and regional) are necessary in order to reach the full potential of growth. Any decision on land requirements from a regional or local perspective will lead to forms of externalities. Managing the negative externalities is our greatest concern, and it is important to offset them with benefits (McDonald \& McMillen, 2003). A one-size-fits-all policy at a regional level can create negative externalities at the local level, while a site-specific policy can lead to negative externalities at the regional level. This attempt to balance has been discussed in other countries as well. One example includes the New Zealand Productivity Commission with their Better Urban Planning report (2016). The review of the land use planning system in New Zealand placed major emphasis on the linkages between regions, while also focusing on improving economic and living opportunities at a more local level. The report outlined that a higher level of flexibility and responsiveness to market demand is an important outcome of any planning system (New Zealand Productivity Commission, 2016). A one-size-fits-all approach may limit a municipality's flexibility, and increase overall costs. If, for example, new infrastructure is required in order to meet specific densities, there will be added costs to develop the municipality - which no doubt will be placed on the developer through fees such as development charges.

The Wharton Index

Another study to understand the impacts of land use regulation was completed by the Wharton School at the University of Pennsylvania (2007). The Wharton Residential Land Use Regulation Index (Wharton Index) was developed to determine stringencies imposed by regulations. This index "can be used in analyses of supply inelasticity or in studies of the impacts 
of regulations on house prices and construction intensity" (Gyourko et al., 2007, 5). Three specific categories are analyzed in the planning process of specific municipalities:

1) General Knowledge- Who is involved in the process - from application to approval, and how many? The significance: If more groups are involved or trying to influence the outcome, this will affect the overall timeline of development

2) What are the regulations/limitations imposed? The significance: The approval process is significantly longer in a highly regulated system than a lower regulated system, again relating back to the timeline of development.

3) What has happened to the cost of housing over time? Were there significant changes over the course of a certain period after imposing regulations? The significance: understanding the positive and negative impacts of land-use regulations.

These three categories were the basis for questions in regard to: (1) local political pressure, (2) state political involvement, (3) state court involvement, (4) local zoning approval process, (5) local project approval process, (6) local assembly process, (7) supply restrictions, (8) density restrictions, (9) open space requirements, (10) exactions requirements, and (11) approval delay context.

It was found that if municipalities were stringent in regard to one of the above eleven categories or indexes, they are generally more likely to be stringent for other categories as well. Of the categories listed above, 1) Time Delay Context and 2) Government Involvement has the greatest influence on the overall development process. To determine what is considered 'overregulated', the research described what is considered to be 'average' regulation - and compared municipalities to that average 
An average municipality is one that fell within an average score on the Wharton Index, +/- 1 standard deviation point. An average municipality tended to have two entities: 1) a committee to approve zoning amendments and 2) a committee to approve project applications. In addition, there was little direct democracy, and no major density restrictions. These municipalities are not strict on providing open space or cash-in-lieu thereof, and a typical application can be approved in an average of six months. So what was highly regulated according to the Wharton Index? A system that contained a high level of state government involvement and a high level of local zoning approval requirements. There was more direct democracy, and much higher open space and exaction requirements. In addition, low density communities were less affordable within municipalities that had greater land use regulations in place. In total, 2,649 municipalities (of varying size) participated in the Wharton School's survey, and therefore was not a small scale approach to determine excessive regulation. Rather, this was a method attempting to incorporate municipalities across the United States (Gyourko et al., 2007). This method should be adopted in Canada to determine average versus highly regulated systems across various regions and municipalities

\subsection{Urban Containment in the GGH and the Implementation of the Growth Plan}

Urban containment has been perceived as necessary to curb rapid expansion of municipalities and create greater efficiency of the urban fabric. It also attempts to limit overall negative externalities on the environment. Regional urban containment policy helps to prevent a "prisoner dilemma" approach for planning at a local level, such that everyone develops what is in the best interest for themselves, and disregard their neighbour (Nelson \& Dawkins, 2004, 73). It is agreed upon that a state or province should have policies in place to direct growth of an 
urban region. However, to what extent should such a policy impact the development of smaller regions and local municipalities? Also, should the policy be flexible in order to improve integration with local municipality progression and requirements? It is suggested that understanding the housing situation can play a significant role in understanding impacts of such regional regulations. For example, observing changes in vacancy rates and housing prices are both indicators of measuring the impact of land use regulation (J. Kim, Deal, \& Chakraborty, 2013).

\subsubsection{The Fraser Institute}

The Fraser Institute (2016) recently completed a similar regulation index to the Wharton Index for the GGH, but at a significantly smaller scale, focusing on the Greater Toronto Area (GTA). Developers and homebuilders were surveyed - with a focus on the time delay between application submission and approval. Time delays in the GTA ranged from 13 months to 30 months, with Toronto averaging about 15.9 months. The local municipalities of York Region were on the longer end of the time delay, averaging 18.8 months. "Zoning by-laws need to be changed to accommodate more than 50 percent of new residential development in 23 out of 26 cities studied" (p. 3) As reported in the survey results, a zoning amendment can take about 3 to 9 months (Green et al, 2016) Provincial policies drive municipal planning policies and thus zoning by-laws. Although we would not notice an immediate change when the Proposed Growth Plan is implemented, it would begin to affect development long term when municipalities complete reviewing and adjusting their respective Official Plans - to conform to the amended Provincial policy. It is suggested that with increased density requirements, more Official Plan amendments and Zoning By-law amendments would be necessary to build more ground-related housing. This 
would add to the overall time lag in development. Developers and homebuilders are concerned that the increase in regulations and time lag is a cause and effect for rising prices of housing. These regulations create upwards pressure in housing prices due to a tightening of the supply market. Although the regulations might create housing units offered at an affordable rate, choices might be limited based on what a future homeowner can afford (i.e. an apartment-style unit) (Green et al, 2016). Similar to the Wharton Index, The Fraser Institute suggests prioritizing the time lag as a means to study the effects of regulation on housing prices.

\subsubsection{Opposing Side of the Argument - RBC and Pembina Institute Report}

In 'Priced Out', a report completed by RBC and the Pembina Institute (2013), the authors describe what they believe has led to housing unaffordability. In 2013, only the 2006 Growth Plan had been implemented. The authors argue that the increase in housing prices was related to the increase in demand of living in ground-related housing within an established community. Such a community allows for "location-efficient living" (p. 7) from both an economic (i.e. jobs) and transit perspective. Should the housing location be unavailable or unaffordable, the reaction is to move incrementally farther - in order to live in a ground-related home. It was reported that a spike in demand of ground-related housing, and hence an increase in prices, occurred in 2005/2006, and that demand has continued until 2017.

The report wanted to understand why prices were rising so quickly. It was stated that from 1980-2010, real income increased by $18 \%$ across Canada, but in that same time housing prices increased by about $80 \%$ (Burda, 2013). With that said, while housing prices continue to rise, new homeowners have the ability to add leverage and cover the costs based on the increase in 
their income as well as lower interest $\operatorname{rates}^{10}$. As a result, there has not been a significant slowdown in the demand for ground-related housing. In addition, the population of the GTA increased 9.2\% from 2006-2011; the national increase was 5.9\%. It is possible that the increase in population and overall incomes have significantly contributed to increased demand in groundrelated housing (Burda, 2013). In fact, Cheshire, Nathan \& Overman (2015) explained that an increase in city size along with improved economic prosperity (i.e. higher wages) motivates buying ground-related housing, and causes some upwards pressure in prices. With that said, housing prices in the GTA have grown significantly faster than median incomes. Furthermore, the supply of ground-related housing has continued to decline significantly. Why is this the case? The Fraser Institute explains that the cost of housing reflects "land availability, building costs, neighbourhood features, and demand within the region" (Green, Filipowicz, Lafleur, \& Herzog, 2016, 3).

\subsubsection{Malone Given Parsons Ltd. Report \& CUR Housing Supply Event}

In a 2015 Growth Plan review by Malone Given Parsons Ltd. (MGP), it was shown that undeleveloped land availability, or more specifically designated greenfield land, has declined since instituting the Provincial policy. While in 2006 there were 34,810 hectares of designated land available, that value decreased to 27,610 hectares by 2011 - 5 years after implementing the Growth Plan, showing there is not much land left for development, and yet that must reach fairly high density targets (Refer to Appendix A). This is an early indicator that while the Growth Plan was directing municipalities on building more dense communities, it came with a loss of available

\footnotetext{
${ }^{10} \mathrm{~A}$ lower interest rate is looked at by owners as a lower monthly cost for their mortgage
} 
land to develop (i.e. serviceable land). This brings us to the current issue of ground-related housing supply within the GTHA. The idea here is that in order for new housing stock to be built for this housing type, greenfield land needs to be made available and serviced for development. The density requirements allow for increases in condominium and stacked townhouse style homes, but limits overall ground-related homes (Malone Given Parsons LTD., 2015b). We cannot simply intensify existing ground-related housing communities with more ground-related housing.

The report further considers the trends of supplying ground-related housing since the Growth Plan was mandated. MGP has suggested that the mandated Growth Plan will further decrease the number of ground-related housing by $12 \%$ come 2031 , being replaced by stacked townhouse and other apartment-style units (refer to Appendix 2). From 2006 to 2031, it has been projected that less than $50 \%$ of housing development will be ground-related housing, a stark decrease from being nearly 75\% of all housing before mandating the Growth Plan (Malone Given Parsons LTD., 2015b). About 220,000 units could have potentially been built as ground-related housing from 2006 to 2031. Instead, those units will be built as stacked townhouses and other apartment-style units within the GGH.

There have been reports, such as, Priced Out, which have suggested there is enough greenfield land available within the GGH to provide ground-related housing, but that density requirements have created some shortages on housing type availability. The Priced Out report also argued that perhaps landowners are holding on to land in order to sell at even higher prices (Burda, 2013). It is important to note the Priced Out Report is discussing all future land available. Reports such as Priced Out lack to identify how much greenfield land is actually readily available 
for development, meaning properly serviced with infrastructure. Once infrastructure becomes part of the picture, the amount of land currently available for development is significantly limited (Amborski, 2016). To refute this point further, Ben Myers (2017) reported that developers in the GTA are uninterested in hoarding parcels of land due to accumulated carrying costs associated with owning (such as interest on loans for owning and constructing). Myers reported that 17.2\% of developers hold on to land for strategic sales purposes, but only do so if the land they are purchasing is site plan or plan of subdivision approved.

In terms of net serviceable land, local municipalities are struggling to develop greenfield sites. "There has been little development in East Gwillimbury and Pickering, for example, because of a lack of water and waste water servicing" (Tuckey, 2016). Municipalities that are in the outer regions of the GGH lack the necessary servicing for development, and the onus is on the municipalities (upper tier and lower tier) to supply that necessary infrastructure (Tuckey, 2016). It has been suggested that this problem could be resolved if the Province truly enforced policy 1.4.1 of the Provincial Policy Statement - which requires a continuous three years supply of serviced land, ready for the development of varying unit types. In addition there needs to be annual monitoring, meaning that actually 4 years of supply are required (Amborski \& Clayton, 2016).

At the same time, there is also an economic burden on municipalities (both upper tier and lower tier) to replace old infrastructure that cannot handle the increased built density. This gets reflected in development charges ${ }^{11}$ - where the burden is moved to the developer, and in so doing

\footnotetext{
${ }^{11}$ These infrastructure improvement costs become reflected in Development Charges to an extent. Under the Development Charges Act in Ontario, there are caps set for municipalities in order to keep the charges within a 10
} 
is affecting the homebuyer with increasing housing costs. MGP (2015) had thought that as a solution, we rethink overused regulations such as Section 37 of the planning act (i.e. Density bonuses), and think of alternative methods to fund public transit and infrastructure improvements. Retooling these policies would begin to alleviate the fees imposed on developers, which become downloaded to the potential homeowner.

Paul Cheshire (2016) presented the idea that we can continue building ground-related housing and developing low-rise, less dense communities - as long as sufficient public transportation and infrastructure is made available. Cheshire explains that growth plans do not help with solving traffic congestion issues unless one provide an acceptable alternative to driving. An improved public transit system can support both high- and low-rise ${ }^{12}$ development. The idea here is to think beyond strong urban containment policy as the only solution to congestion and environmental issues, if the policies themselves are ignoring long-term economic concerns - such as rapidly increasing development charges and creating an inelastic supply of housing. Urban containment policy with balanced flexibility from both the regional and local sides are considered necessary for effective development (Nelson \& Dawkins, 2004).

\subsection{Preliminary Applications to Regulation and Housing Costs}

\subsubsection{Glaeser, Gyourko, \& Saks Manhattan Study - Construction-Purchase Price Gap}

Applying Glaeser, Gyourko, \& Saks' study (2005) on Manhattan is a good start to understanding whether there might be a relationship between rising housing costs and planning regulations/restrictions. Glaeser et al measured the difference between housing prices at market

\footnotetext{
year historic average. The remaining costs will be covered by revenues such as taxes and user charges (Nicola Crawhall and Associates, 2015)

12 i.e. ground-related housing
} 
level and the marginal costs of constructing housing- in developing what is called a 'regulatory tax'. In Manhattan purchasing a condo was almost double the cost of producing it. Glaeser et al claims that since the market is competitive, developers will not sell much higher than the marginal costs of construction. There must be a form of regulation causing significant pricing gaps. Demand could be causing upwards pressure on costs, but why would the upward pressure create prices that are double that of construction? This is what Glaeser et al hoped to determine by understanding the regulatory tax.

We can begin to see similar upwards pressure in pricing for condominiums in the GTA (Urbanation, 2017). Since 1981, Urbanation has been recording condominium sales in the GTA, and 2016 was the first year of decline for construction completions in response to the slowdown in absorptions. The average rent for a single unit is $\$ 1,990$ per month in the GTA; and has reached $\$ 2,134$ per month in the City of Toronto. It is being suggested that as ground-related housing becomes less affordable, prospective owners are considering condominiums as an option for housing. There will need to be a market response in order to keep the condominium market stable in the GTA (Urbanation, 2017).

\subsubsection{Applying the Wharton and Fraser Indexes}

Using the Wharton Index method, the Growth Plan can be evaluated based on its extent of regulatory power. By this we mean the extent to which planning decisions for municipalities are influenced by the Province, and the extent of a time lag in development as a result. These values can be related back to metrics that show changes in housing supply and costs. MGP has been providing ongoing housing information relevant to this topic, and can be useful to compare with the Proposed Growth Plan. In the case of Ontario, we still have a high level of Provincial 
involvement and a relatively high direct democracy for planning - as Section 17.15 of the Planning Act requires public consultation for development proposals (Government of Ontario, 1990). The mandated Growth Plan should be studied to compare the time lag factor before and after policy implementation. Also, the median income change should be studied, to see if there is a strong relationship between the level of regulations, median incomes and housing costs. As outlined by the Wharton Index, both time lag and increase in median incomes are good measures for land use regulation. It was observed that areas with higher median income also had higher regulations (those are the people which could afford housing) (Gyourko et al., 2007). Understanding these changes from the original Growth Plan will inform on forecasting the proposed policy amendments.

The Fraser Institute (2016) has done some preliminary work on measuring land use regulations in metropolitan areas across Canada (including Montreal, Toronto, and Vancouver). It was found that on average, that land availability was the greatest factors for increased purchase prices. The time between development application submission and issuing of a building permit has also had a significant impact on prices. Again, if the Growth Plan can be measured to the extent of how it adds to time lag, it will effectively inform on improving the proposed amendments. This will be done based on the change in infrastructure requirements in order to meet prescribed density requirements.

\subsubsection{Case Study: Washington DC}

A similar story exists in Washington DC, and the purpose of this case study is to segue into my case study of York Region. The Urban Institute (2016) completed a study on the strategies for housing in Washington DC, where the supply of ground-related housing decreased significantly 
while demand for the housing-type continued to rise post-recession. It was calculated that in order to meet housing demand until 2032, about 27,000 housing units needed to be constructed each year. Within the last ten years that target was not achieved, with the closest being 26,000 units in 2006. Limitations were set within Washington DC and its surrounding counties. This has come in the form of county size constraints and/or political regulation constraints, for example protection of agricultural lands or intensification requirements. An implication of these constraints is a tightened supply of all forms of housing, but specifically ground-related. As a general trend, older adult populations remained in ground-related housing, while the millennial population increased and added to the demand for housing.

It is important to understand the constraints within the specific region in order to try and bring the necessary supply of housing units. One of the main constraints found in Washington DC was limitations on physical area for development. The combination of preservation of agriculture land and height restrictions both allude to a delay in providing the necessary supply of housing units. Overall two strategies were discussed to improve both high- and low-density development with the constraints in place. For high density, the strategy was to build along transit corridors, especially lands that are under-utilized but have that direct connection to public transit. In this scenario there would be more land value capture potential for the municipality, along with fewer infrastructure requirements. For example, Merrifield, an "industrial suburban crossroads in Fairfax (Virginia), has developed into a mixed-use town center with 1,000 housing units, a multiplex theatre, 125,000 square feet of office space, and 500,000 square feet of other nonresidential space" (Blumenthal, McGinty, \& Pendall, 2016, 19). 
For low-density, ground-related housing, one of the main strategies put in place to increase units is adding "accessory dwelling units" (p. 21). It brings an opportunity to create a small rental market within homes, as well as provide a side pocket of income to provide to the homeowner. This is all part of increasing density in these neighbourhoods without completely repurposing low-density neighbourhoods. The same would apply for the construction of new communities as well. New policies would emphasize the importance of housing choice, in order to meet with housing demand. A range from small units to larger ground-related dwellings should be made available to the general public (Blumenthal et al., 2016). Reflecting back to the Urbanation report (2017), there is increasing demand in condominiums as a result of the increasing unaffordability of ground-related homes. It is important to discuss the necessity of housing choice for the purposes of meeting demand, and maintaining a level of market stability. As Jane Jacobs put it, "the point of cities is multiplicity of choice" (Wollen \& Kerr, 2002, 259). This should apply to all levels of living in a city, from access to transportation, to a diverse group of housing units.

\subsection{Takeaways from the Literature Review}

Past research has shown that regional regulation has significant impacts on the planning process for municipalities, and a way to measure these impacts is by understanding housing supply and prices. The Growth Plan for the Greater Golden Horseshoe claims to have good intentions for urban containment, but fails to undertake an economic analysis (costs and benefits) or outlook on the effects associated with implementing such a regulation. Regulations in general attempt to prevent negative externalities and impacts onto society as a whole. Furthermore reports suggest it is difficult to effectively measure the direct correlation between planning regulation and 
housing supply (Luger \& Temkin, 2000). We can attempt to measure and understand the outcome of regional regulation based on elements in the development process. This includes the gaps between construction costs and purchase prices, and looking into time lags in development with a regulation index.

In the GGH, we can also see a tightened supply market for housing, as demand continues to rise and not be met. Perhaps the Province can seek a less regulated-heavy system, one which would give municipalities more choice for growth and thus provide a broader range of housing for potential homeowners. As the paper continues to look into forming an analysis of improving the Proposed Growth Plan, it is important to keep these ideas in mind, as ultimately the outcome is to form a regulated system that makes the planning process more efficient, and as a result increases supply of ground-related housing which is affordable. There are four specific takeaways from the literature review to keep in mind for the remainder of this paper, especially the case study. Each takeaway has been connected to a specific study mentioned in the review:

1) A municipality's status on meeting infrastructure needs (Malpezzi \& Bertaud);

2) The extent to which the Growth Plan takes into consideration market demands (MGP, Cheshire);

3) Time lags between the application submission and approval for site plans or plans of subdivision, along with associated costs (Wharton Index); and

4) Development-pricing gaps in the GTA (Glaeser et al). 


\section{Chapter 3 York Region: A Case Study}

This chapter provides a case study on the Regional Municipality of York (York Region). The purpose of this case study is to show the connections between regional land use regulation and the supply of housing. This case study looks into the development status of the Region and understands the Region's response to the 2006 Growth Plan. In addition, this case study provides a brief overview of how the Proposed Growth Plan will impact development for York Region. Refer to Figure 1, on page 26, for a geographic context of York Region.

York Region is one of the fastest growing regions in the Greater Toronto Area, contributing $23.8 \%$ of the Area's growth in 2015 . The Region matches the two highest areas of growth - Toronto at $24.2 \%$, and the Region of Peel at $27.3 \%$. The population has reached nearly 1.2 million people and is expected to reach 1.5 million by 2031 and 1.79 million by 2041 . These growth forecasts were directed by the 2006 Growth Plan (Committee of the Whole, 2016). How is York Region attempting to maintain this growth, and how has the Region reacted to the original Growth Plan and proposed density changes? These are key issues to understanding and applying a similar structured study to other upper tier and single tier municipalities in the GGH. In addition, understanding the ability for York Region to supply the necessary serviced land is crucial to understanding the limited supply of ground-related housing.

York Region is broken down into nine local municipalities: Town of Aurora, Town of East Gwillimbury, Town of Georgina, Township of King, City of Markham, Town of Newmarket, Town of Richmond Hill, City of Vaughan, and Town of Whitchurch-Stouffville. The Region's boundaries are Simcoe County \& Lake Simcoe to the North, Toronto to the South, Durham Region 
to the East, and Peel Region to the West. Both the Oak Ridges Moraine and Greenbelt run through York Region.

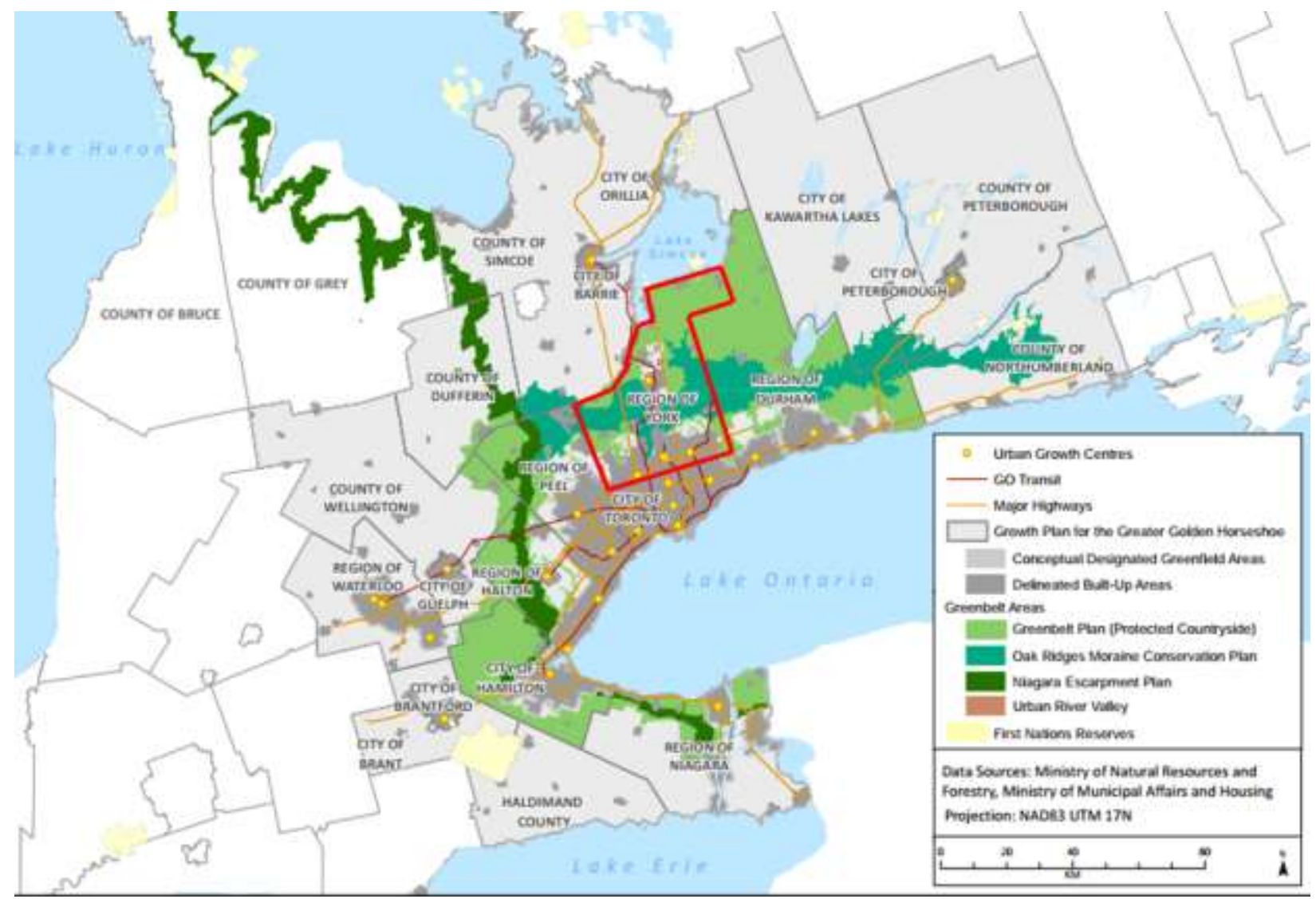

Figure 1: Map of the Greater Golden Horseshoe, York Region is outlined in red. Source: Ministry of Municipal Affairs and Housing, n.d.

The Regional Municipality has written numerous responses to the 2006 Growth Plan, and most recently submitted a report on proposed revisions to the 2016 proposed density amendments. A summarization of the policies impacting the Region's development will help with analyzing the Region's current strategy for growth and the ability to supply serviced land. Consultation with various staff at York Region assisted with selecting appropriate documents to study in order to fully understand the Region's response to the Growth Plan. There is also an 
analysis on housing starts, and change in costs - to see how the Proposed Growth Plan might further impact ground-related housing.

\subsection{York Region Housing Data}

My analysis of York Region begins by looking at the change in housing starts in the last ten years. Looking at Figure 1, a general decline is noticeable in starts for ground-related housing, which includes single-detached, semi-detached and row/town housing. Aurora and East Gwillimbury have seen a sharp increase in ground-related housing starts, a lot to do with improved servicing infrastructure put in place. However the remaining seven municipalities have showed very little change, or declines. Can we find the data contributing to the significant slowdown in housing starts?

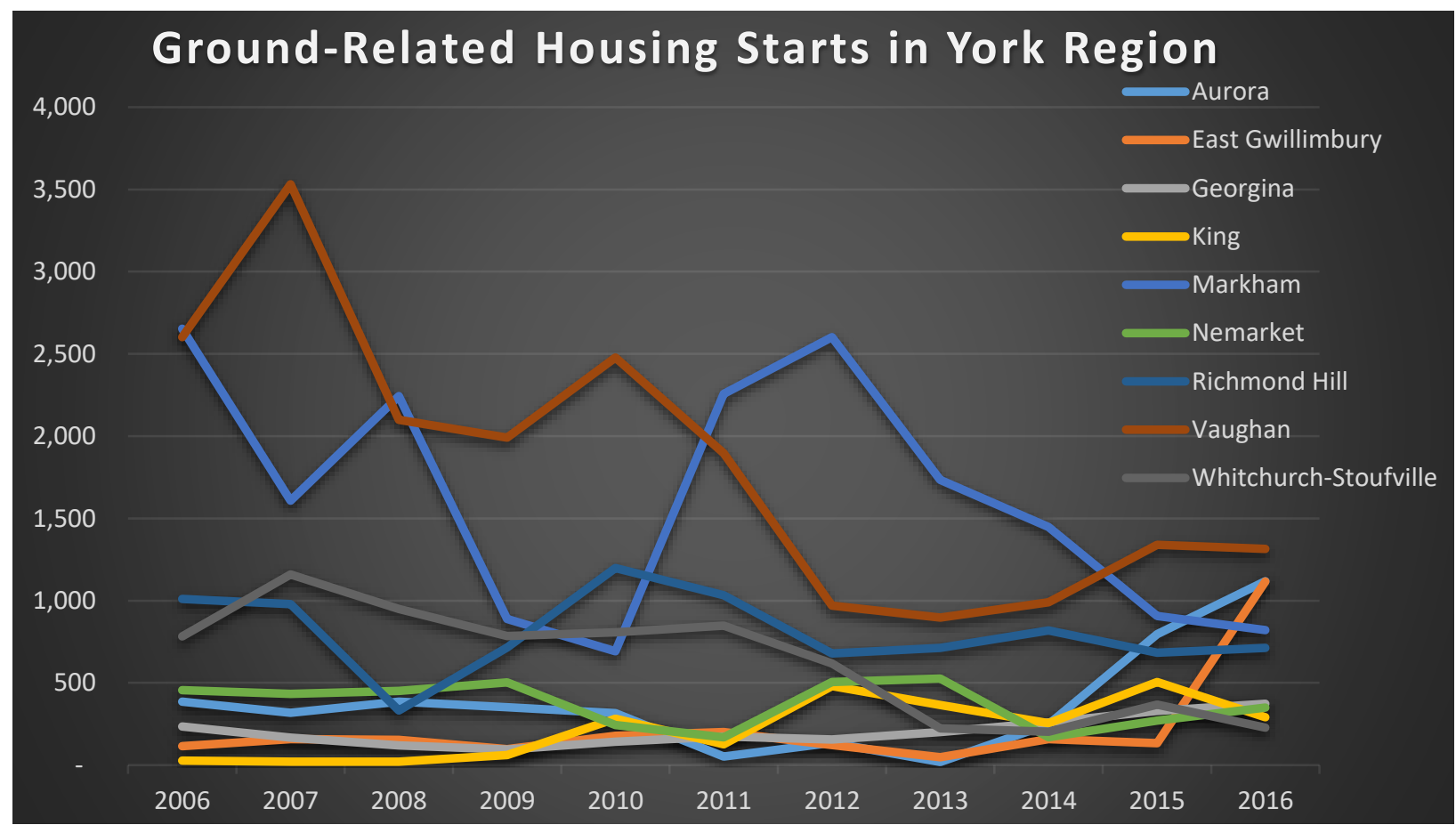

Figure 2: Comparing the number of housing starts (by year) in all nine municipalities within York Region. Source: CMHC, 2016

Applying the Glaeser et al method of pricing gaps between construction and purchase prices is a helpful indicator for regulation and planning costs. The hypothesis is that the marginal 
construction costs have not increased significantly over time, while the purchasing price of new housing have. With data collected from the Altus Construction Cost Guide from 2006-2016 ${ }^{13}$, there can be an understanding of how costs have changed over time to build various housing types.

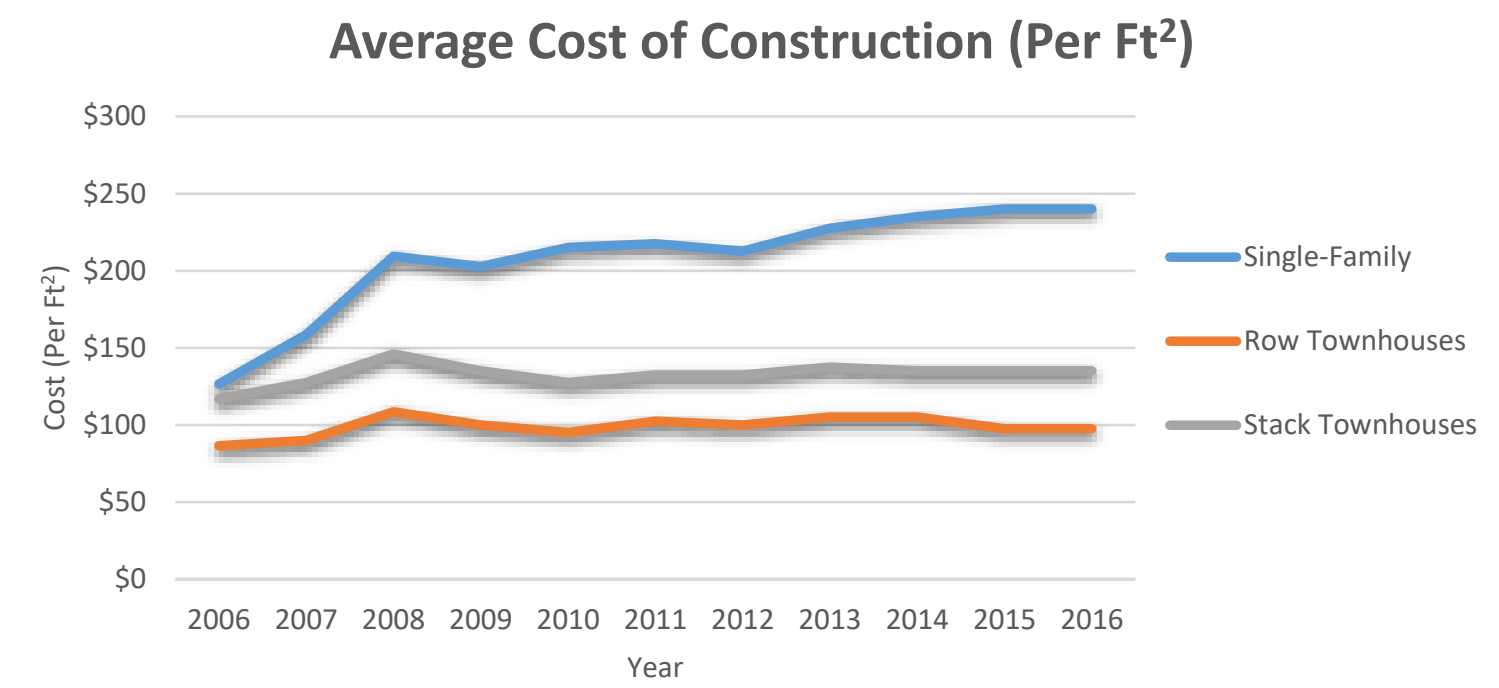

Figure 3: Average Cost of Construction in the Greater Toronto Area. Source: Altus Construction Cost Guides, 2006-2016

With the exception of a steeper increase from 2007-2008, increases in construction costs have remained relatively stable. Single-detached home construction costs have fluctuated \$5-\$15 per square foot each year, while row and stack townhouses have seen very little change. This can be compared to the change in the average cost of purchasing these housing types over time:

\begin{tabular}{|c|c|c|}
\hline \multicolumn{2}{|c|}{ Table 1: Toronto CMA Average Absorbed New Housing Unit Prices } \\
\hline Housing Type/Year & Single- \& Semi- Detached & Year-Over-Year \% Change \\
\hline 2006 & $\$ 440,224$ & - \\
\hline 2007 & $\$ 486,258$ & $10 \%$ \\
\hline 2008 & $\$ 515,519$ & $6 \%$ \\
\hline 2009 & $\$ 540,757$ & $5 \%$ \\
\hline 2010 & $\$ 576,272$ & $7 \%$ \\
\hline
\end{tabular}

\footnotetext{
${ }^{13}$ Altus provides construction costs as ranges in their annual report. The averages of those ranges were calculated and compared across 10 years, from 2006 to 2016 .
} 


\begin{tabular}{|c|c|c|}
\hline 2011 & $\$ 623,488$ & $8 \%$ \\
\hline 2012 & $\$ 632,593$ & $1 \%$ \\
\hline 2013 & $\$ 699,750$ & $11 \%$ \\
\hline 2014 & $\$ 773,455$ & $11 \%$ \\
\hline 2015 & $\$ 896,026$ & $16 \%$ \\
\hline 2016 & $\$ 935,898$ & $4 \%$ \\
\hline
\end{tabular}

Table 1 Source: CMHC, 2017

\begin{tabular}{|c|c|c|}
\hline \multicolumn{3}{|c|}{ Table 2: York Region Average Absorbed New Housing Unit Prices } \\
\hline Housing Type/Year & Single- \& Semi- Detached & Year-Over-Year \% Change \\
\hline $\mathbf{2 0 1 0}$ & $\$ 525,334$ & - \\
\hline $\mathbf{2 0 1 1}$ & $\$ 555,091$ & $6 \%$ \\
\hline $\mathbf{2 0 1 2}$ & $\$ 640,528$ & $15 \%$ \\
\hline $\mathbf{2 0 1 3}$ & $\$ 752,532$ & $17 \%$ \\
\hline $\mathbf{2 0 1 4}$ & $\$ 806,015$ & $7 \%$ \\
\hline $\mathbf{2 0 1 5}$ & $\$ 909,955$ & $13 \%$ \\
\hline $\mathbf{2 0 1 6}$ & $\$ 1,002,067$ & $10 \%$ \\
\hline
\end{tabular}

Table 2 Source: CMHC, 2017

It seems the average cost of ground-related housing, especially in York Region, has risen significantly in the last several years, while construction costs saw only slight increases. In these years, it seems the increases in prices of ground-related homes and the relatively stagnant construction costs suggest the potential dilemma for ground-related unit development based on recent density requirements, along with an increasing demand for the specific housing type. Even if construction costs increased $10 \%$ per year in the last five years - this should not cause $16 \%$ annual increases in housing prices - further suggesting a missing gap, or as Glaeser et al suggested, a regulatory tax. The gap is potentially filled with the backlog of costs associated with regulation and servicing (Glaeser et al, 2005). As municipalities continue to raise fees in order to provide the necessary servicing, this will be reflected within the construction-purchase price gap as the price of new homes increases (Burda, 2013). 
Population Projection by York Region (Outlined in Appendix D): Within the Water \& Wastewater and Transportation Master Plans, the Region has listed the top municipalities for population growth by 2041, which include East Gwillimbury (100,000 people), Markham (180,000 people), Richmond Hill (80,000 people), and Vaughan (160,000-170,000 people). This growth is becoming noticeable with the significant increase of housing starts in East Gwillimbury over the last several years.

\subsection{Changes in Median Income}

Understanding the change in median income can also provide an understanding into rising housing prices (Cheshire, 2016). The rise in economic well-being attributes to increased willingness to buy higher valued property, which relates to increased demand in specific housing types, such as ground-related housing. Median household income has grown at a steady rate of $17 \%{ }^{14}$ every five years. In 2006, the median household income in York Region was $\$ 81,872$, and in 2011 that value rose to $\$ 98,244$. Although 2016 census data for median household income is not yet available, we can predict that value to be at least $\$ 114,616$ based on the current 5 year trend. Along with a steady increase in median income, interest rates for mortgages have continued to decline. The average variable rate in 2006 was $6.275 \%$, whereas in 2016 , the rate has dropped to $3.14 \%$. The interest rate has been declining since 1980, when the variable rate was about $14.0 \%$ (Bank of Canada, 2017).

\subsection{Changes in the Supply of Land}

\footnotetext{
${ }^{14}$ These values were calculated using census data from Statistics Canada (2006 \& 2011).
} 
A way of measuring York Region's the change in housing supply is by comparing the new supply by unit since 2006. Overall from 2006, York Region reported the supply of all designated greenfield land by unit type. There were 12.2 years supply of single-detached homes, 10.0 years supply of semi-detached homes, 12.8 years supply of row houses, and 18.1 years supply of apartments. This was total expected supply of greenfield land. The housing mix for 2006 was as shown in Table 3 below:

\begin{tabular}{|l|l|}
\hline \multicolumn{2}{|c|}{ Supply by Housing Unit Type 2006} \\
\hline Single-Detached & $52 \%$ \\
\hline Semi-Detached & $10 \%$ \\
\hline Row & $19 \%$ \\
\hline Apartments & $19 \%$ \\
\hline
\end{tabular}

Table 3: Breakdown of Housing Units by type in 2006. Source: Planning and Economic Development Committee, 2006

By looking at housing completions 5 years later, in 2011, the proportion of annual supply remained relatively the same. It is important to note that in 2010, the number of completed dwellings by type became available for York Region (CMHC, 2017).

\begin{tabular}{|l|l|}
\hline \multicolumn{2}{|c|}{ Completions by Housing Unit Type } \\
\hline Single-Detached & $4,039(54 \%)$ \\
\hline Semi-Detached & $692(9 \%)$ \\
\hline Row & $1,302(17 \%)$ \\
\hline Apartments & $1,417(19 \%)$ \\
\hline
\end{tabular}

Table 4 Note. Data collected from Toronto CMA, Completions by Dwelling Type by Zone, CMHC, 2017

Looking 10 years later in 2016, we can see a significant shift towards apartment style units, about $48 \%$ of all new housing stock.

\begin{tabular}{|l|l|}
\hline \multicolumn{2}{|c|}{ Completions by Housing Unit Type } \\
\hline Single-Detached & $2,198(31 \%)$ \\
\hline Semi-Detached & $164(2 \%)$ \\
\hline Row & $1,319(19 \%)$ \\
\hline Apartments & $3,335(48 \%)$ \\
\hline
\end{tabular}

Table 5 Note. Data collected from Toronto CMA, Completions by Dwelling Type by Zone, CMHC, 2017 
Over the last ten years, there has been an increase in apartment units, with a decrease in single- and semi-detached houses, and the proportion of row houses have remained relatively stable. While this is creating a mix of housing types, there is still limited choice. While York Region reported 6 years supply of housing units over the next 3 years, part of its calculation is assuming a significant increase in multiple unit housing (Committee of the Whole, 2015)(Regional Municipality of York, 2016a). However, to this point increases in multiple unit housing has been reflected in significant increases of apartment units. The Ontario Home Builder's Association (2017) has suggested an increase in medium-density buildings, such as row/townhouses - in order to increase housing choice for new homeowners.

\subsection{Master Plans and the Official Plan}

The remainder of this chapter considers different methods outlined in the literature review to understand the impacts of a one-size-fits-all policy. By understanding the future development of York Region, we can begin to understand what Malpezzi and Bertaud suggested - such that a general regulation can easily not match what the lower level public or private sector is trying to accomplish - and the costs begin to outweigh the benefits. The Wharton Index can also potentially apply here, by showing the length of time and government involvement required in order to allow any development to occur.

The Region's population is expected to grow from its current 1.16 million to 1.79 million people by 2041. This is resulting in prosperous opportunity for development, while also requiring important additions and improvements to the Region's infrastructure. It is estimated two-thirds of this population growth will end up in Markham, Richmond Hill, and Vaughan. A common 
trend that will be noticed while reviewing specific York Region planning policies is the change required in order to meet growth. Each respective plan suggests reviews will be required to meet new targets and/or a delay in servicing while these plans are reviewed and new capital budgets are determined. These changes are all factors to the time progress of development in York Region and what is helping to limit annual supply of ground-related housing.

\subsubsection{The Water and Wastewater Master Plan}

York Region has developed a masterplan for water and wastewater $(W M P)$ in order to work with its growing population. Refer to Appendix B for the timetable of improvements in Markham, Richmond Hill, and Vaughan. In the last decade, it has become increasingly difficult to develop water and wastewater servicing in municipalities with land covered by the Greenbelt Plan. "The Greenbelt plan restricts the extension of lake-based water and wastewater servicing" (Regional Municipality of York, 2016c). Furthermore, the Oak Ridges Moraine Conservation Plan restricts expansion of partial services. Both Lake Ontario and Lake Simcoe water Systems cannot be expanded much more without connecting them together. These regional restrictions are impacting the development of lower-tier municipalities, such as East Gwillimbury. Is this a partial indicator in understanding the slow-down of ground-related housing supply?

"The main purpose of the Master Plan Update is to determine the water and wastewater infrastructure requirements needed to support the revised growth forecasts identified in Amendment 2 to the Growth Plan for the Greater Golden Horseshoe" (p. 8). "Growth will strain existing water and wastewater systems and require new infrastructure and servicing strategies in order to continue to provide safe, reliable and sustainable water and wastewater services" (p. 9). The current structure of water \& wastewater servicing for York Region is outlined in Appendix 
C. As can be observed, most municipalities receive water from either only Lake Ontario or Lake Simcoe. There are some areas within municipalities that are serviced either with a combination of a major lake and groundwater, or completely from stand-alone systems.

The WMP outlines key concerns to be addressed in the coming years in order to move forward with development in York Region. It is crucial to provide more water services to East Gwillimbury and Newmarket by creating a new pump station in Lake Simcoe and building the Upper York Sewage Solution. It is estimated that about 7,400 ground-related units are delayed due to the lack of proper water servicing (Malone Given Parsons LTD., 2015a)The requirement to build at even higher densities puts even more pressure to develop these potential pockets of ground-related housing, as other designated greenfield areas are developed with apartment-style units to meet density requirements.

The Region is restricted on the amount of water transferred between Lake Ontario and Lake Simcoe, which has required the Region to consider alternative ways to supply the necessary water capacity for new development. In addition, determining how to increase water servicing without interfering with the Greenbelt or Oak Ridges Moraine is still an ongoing conversation. The Oak Ridges Moraine creates a divide between watersheds flowing to Lake Ontario on the south side and flowing to Lake Simcoe on the north side. The Region wants to improve servicing capacity with more connections to the York Durham Sewage System and the construction of the Upper York Sewage Solution, which is not expected to be completed until 2024 (the Environmental Assessment was completed in 2014). York Region continues to be faced with physical geographic constraints, which are regulated by political conservation constraints. The WMP strategy will remain the same even if the Proposed Growth Plan new densities are adopted. 
The Region will attempt to maintain the same timelines for servicing, although delays are expected should the new proposed densities of the Growth Plan be implemented. This is due to new environmental assessments for intensification areas, allocating the correct funding in future capital budgets, and an overall review \& update of the current WMP (Regional Municipality of York, 2016c). Finally, Crawhall and Associates (2015) outlined requirements for intensifying urban centres in York Region - to achieve 200 people and jobs per hectare as outlined by the Province. One of the biggest factors mentioned was improvements to water and wastewater servicing:

\begin{tabular}{l|c|l}
\hline \multicolumn{1}{|c|}{ Municipality and UGC } & $\begin{array}{c}\text { Residents and } \\
\text { Jobs per Ha } \\
\text { Density Target }\end{array}$ & $\begin{array}{c}\text { Target reachable } \\
\text { by 2031? }\end{array}$ \\
\hline York Region & 200 & $\begin{array}{l}\text { Depends on water } \\
\text { and wastewater }\end{array}$ \\
\hline Markham Centre & 200 & $\begin{array}{l}\text { Depends on water } \\
\text { and wastewater }\end{array}$ \\
\hline $\begin{array}{l}\text { Vaughan Corporate } \\
\text { Centre }\end{array}$ & 200 & $\begin{array}{l}\text { Depends on } \\
\text { Yonge line } \\
\text { extension }\end{array}$ \\
\hline $\begin{array}{l}\text { Richmond Hill / angstaff } \\
\text { Gateway }\end{array}$ & 200 & $\begin{array}{l}\text { Depends on water } \\
\text { and wastewater }\end{array}$ \\
\hline Newmarket Centre
\end{tabular}

Figure 4: Note, reprinted from Implementing the Growth Plan: Seeking Provincial and Municipal Alignment to Support a Prosperous Ontario by Nicola Crawhall and Associates, 2015

\subsubsection{Transportation Master Plan (TMP)}

York Region has five major objectives for transportation improvements to 2041: 1) Create a World Class Transit System, 2) Develop a Road Network Fit for the Future, 3) Integrate Active Transportation in Urban Areas, 4) Maximize the Potential of Employment Areas, and 5) Make the Last Mile Work. 
Efforts are being made by the Region to improve the current road block system (Refer to Appendix D), but as it stands now, the regional system is made of arterial roads, separated by about $2 \mathrm{~km}$, with few collector roads in between that are continuous throughout the Region.

York Region has specified that this has, and will continue, to contribute towards road congestion issues. An improved road system along with an effective public transit system must be put in place to accommodate growth. As a positive step towards completion of various road projects, York Region's Transportation Master Plan is covered by "phases 1 and 2 of EA (Environmental Assessment) requirements for roads." This can help overall with implementing new transit networks in the Region by passing EAs for a larger group at once.

The TMP has included the Province's 2006 Growth Plan and The Big Move ${ }^{15}$ as a foundation for the development of transit in the Region. The Region is using both of these policies as a framework for development - specifically to build at higher densities near current and future major transit corridors, while also providing multiple modes of transit for the whole Region. "Assumption and direction used in the 2016 TMP are based on the approved Provincial Policies and Plans including the PPS (2014), the Growth Plan for the Greater Golden Horseshoe..."(Regional Municipality of York, 2016b, 36) The transportation numbers and projections are based on the supply and demand calculations of the previous Growth Plan, which are summarized in a municipal comprehensive review completing in 2015.

\footnotetext{
${ }^{15}$ The Big Move is the Regional Transportation plan for the Greater Golden Horseshoe put in place by Metrolinx, a transportation agency of the Provincial government.
} 
Since updating the TMP in 2015, Metrolinx is conducting a review of The Big Move, to supply transit that supports population and employment growth to $2041^{16}$ for the GGH. The Review is expected to be completed in 2017, at which point York Region will require a review of their TMP to conform to the plan for the GGH. This will require new transit projects to support increased density and intensification requirements (Metrolinx, 2016). There is concern that with no transition time between approval of the Proposed Growth Plan and implementation of the actual density requirements, development will significantly slow-down while York Region sets out its necessary policies and master plans to conform to the amended Growth Plan.

It is important to note here the intrecancies that have gone into calculations for the TMP. Having a revised Growth Plan will require changes to growth calculations and the TMP itself, to ensure updated policies that outline how the Region will build transit for increased densities, especially in designated greenfield areas. The 9 lower-tier municipalities have not been studied, however they would also need to meet similar requirements from a more local perspective. The constant cycle of changes in planning policies is important to take note of and will be discussed in greater detail in the next section on discussions with developers.

\subsubsection{York Region's Regional Official Plan}

The 2016 Office Consolidation of the 2010 Regional Official Plan (ROP) has outlined intensification requirements for each lower tier municipality for growth and is summarized below in Figure 2. This is a framework for maintaining growth from 2006 until 2031. Growth is being emphasized for Markham, Richmond Hill, and Vaughan. The Region has asked for each

\footnotetext{
${ }^{16}$ The Current Regional Transit Plan for the Greater Golden Horseshoe is based on growth calculations to 2031, and in conformity to the 2006 Growth Plan.
} 
municipality to "plan for a range and mix of housing, taking into account affordable housing needs" (p. 86).

\begin{tabular}{lc}
\hline Municipality & Units \\
\hline Aurora & 3,140 \\
\hline East Gwillimbury & 1,030 \\
\hline Georgina & 2,690 \\
\hline King & 920 \\
\hline Markham & 31,590 \\
\hline Newmarket & 5,250 \\
\hline Richmond Hill & 15,300 \\
\hline Vaughan & 29,300 \\
\hline Whitchurch-Stouffuitle & 1,500 \\
\hline York Region & 90,720 \\
\hline
\end{tabular}

Figure 5 York Region Intensification Targets from 2006-2031. These numbers were determined by looking at population growth to 2031, the required housing needs - and applying $40 \%$ of this growth to be accommodated through intensification. Reprinted from the Regional Official Plan, 2015.

The 2010 OP did not receive approval until 2015. With approval of the Proposed Growth Plan, the Region would have to complete a review of the ROP and amend it in order to conform to new 2016 requirements. In addition, all nine municipalities and their respective Official Plans would undergo similar reviews to conform to the ROP. Three significant Regional Official Plan Amendments (ROPAs) were created in 2010 as part of a municipal comprehensive review, to match the Growth Plan's original density requirements. These amendments are known as ROPAs 1, 2, \& 3, representing urban boundary expansions in East Gwillimbury, Vaughan, and Markham respectively. Upon approval, the purpose of these expansion areas would be to meet population and employment growth forecasts in response to the 2006 Growth Plan (Planning and Economic Development, 2010). There has been ongoing debate on the approval of these urban boundary expansions due their proximity to conservation areas, such as the Greenbelt and Oak Ridges Moraine. With the approval of the Proposed Growth Plan, there is concern from the Region that 
these urban boundary expansions will not be possible to approve if the 80 people and jobs per hectare apply to these areas as well.

\subsection{York Region's Response to the Proposed Density Requirements}

There were a number of concerns regarding the Proposed Growth Plan outlined by York Region. One of the main concerns is that actual results from the 2006 Growth Plan have not really come into effect. Many lower tier municipalities still have not passed their most up-to-date official plans, and are still going through the OMB process. After spending ten years to implement the Growth Plan into local planning policies (i.e., official plans), major changes would be required again if the Proposed Growth Plan receives approval.

The Region has asked for the densities to be phased in, similar to the 2006 Growth Plan, where the density requirements were to be phased in by 2015. The Region also suggested maintaining the current density requirement of 50 people and jobs per hectare for all designated greenfield areas. Otherwise, new residential units will be built at high densities in order to meet the average 80 people and jobs per hectare. The Region has suggested this could be offset with higher density requirements around transit corridors. In order to reach higher densities in these areas, York Region has suggested to "Revise the Growth Plan to identify planned transportation infrastructure including municipal rapid transit corridors and stations, required to accommodate growth to 2041" (Planning and Economic Development, 2016, 7).

The mandated 2006 Growth Plan outlined a transition period, requiring municipalities to adopt all policies by 2015 . The Proposed Growth Plan has no such transition, meaning immediate adoption of policies upon approval. Due to the higher density required in designated greenfield areas and increased intensification, development charges would be affected - due to increased 
costs of servicing those areas, as well as replacing older infrastructure in areas of intensification (Planning and Economic Development, 2016). In an analysis of the 2006 Growth Plan completed by Nicola Crahwall \& Associates (2015), the average costs in York Region for infrastructure improvements, to maintain intensification targets, between 2012 and 2014 was $\$ 730$ million. In terms of conforming to the Province's requirements, York Region has continuously met the 40\% infill development target. In recent years, the Region has been building towards a $50 \%$ target. The Region is hoping to continue increasing its intensification target, but will require a transition period to meet the proposed $60 \%$ target (Cohrs, 2017). 


\section{Chapter 4 Response from Developers}

Now that there is an understanding of development in York Region as a whole, the discussion can shift to developers actively working on projects in the Region. Three developers were interviewed, talking about the planning process and general development situation from their point of view, along with the noticeable changes over the last ten years. As noted above, both the Wharton Index and Fraser Institute Report outlined time lag and the availability of land as significant contributors to the supply of housing.

\subsection{The Project Approval Timeline}

Depending on the status of the land acquired, an actual building permit can be achieved anywhere from 1 year to 5-10 years after submitting a development application. For York Region in 2012, the average application process was reported between 5 and 8 years (York Region, Planning and Economic Development, 2012). Compared to a survey for the GTA completed by Ben Myers (2017), 43\% of developers reported that it takes 2-4 years to get approval for a plan of subdivision, $28 \%$ said less than 2 years, and 25\% said between 5 and 10 years. This is entirely dependent on a number of factors:

1) Is the land serviced with the necessary infrastructure to develop? For example, water, transportation, utilities, etc.

2) The designation status of the subject land. Questions begin to arise such as: Is the land zoned for the development or are amendments required? Is the subject land under an Official Plan review, for example York Region Official Plan Amendments 1, 2 and 3 ?

3) The municipal approval process: There are now multiple departments within a municipality that are required to sign off on an application in order to receive approval. 
To name a few, a typical development proposal will go through engineering, environmental and/or conservation authorities, transportation, public works, community planning, etc. There are multiple facets in the municipal planning approach today throughout York Region's municipalities, and should any amendment to an application file be required, all departments would be required to sign off on the changes.

Acquiring subject lands that have an almost complete file can still take one to two years for approval of site plan or plan of subdivision, otherwise the length of time can go closer to 5-10 years for certain ground-related subdivisions. Furthermore, some developers suggest "the cost of navigating the approval process is $\$ 46,000$ per unit" (Myers, 2017, 42). There is growing concern that amending the density requirements of the Growth Plan would require lengthy changes in Official Plans, constant amendment applications for zoning by-laws, along with significant changes to builders' approaches to development, which would indeed slow down the planning process.

\subsection{High Density and Zoning Changes}

It was discussed during my conversation with developers in York Region, that the density requirement of 80 people and jobs per hectare in designated greenfield areas will be very difficult to meet. The concern comes from not excluding greenfield lands already under registered lot approval or plan of subdivision approval, just not yet developed. The 'built boundary' in municipalities has not been extended by the Province to include these lands that will soon undergo construction. Since a significant proportion of the area will already be built at lower densities, the remaining designated greenfield areas will have to be developed at much higher densities (i.e. more than the Growth Plan requirements) in order to meet the average of 80 people 
and jobs per hectare. Significant changes to transit and water servicing would be required to sustain large swings in population to urban fringes. This can further impose higher development charges in order to maintain such high densities of growth in under serviced areas of York Region. In order to achieve the outlined growth, a consideration is to build at higher densities near existing and proposed transportation corridors. The development of Vaughan Metropolitan Centre is an excellent example of development resulting from significant transit improvements (i.e. the Toronto-York Spadina Subway Extension and BRT for Highway 7).

With the Proposed Growth Plan, there is little to no information regarding the requirement of municipalities to update zoning, especially now that municipalities will be required to build at higher densities. The process of zoning amendments for any form of higher density building continues to add on the lengthy process of receiving site plan or plan of subdivision approval. 


\section{Chapter 5 Conclusion and Next Steps}

The purpose of this research paper was to provide an understanding on land use regulation and its implications on the planning process for a municipality, and the resulting supply of ground-related housing. This was done by reviewing the Growth Plan's density targets, looking at past research which studied the connections between regulations and planning, and using York Region as an example for outcomes on the planning process by regional regulation (i.e. Growth Plan). The findings suggested the mix of land constraints and time lags for development both contribute to the rising cost of ground-related housing.

The Growth Plan has led to intensification of the built environment within the GGH, yet it has also contributed to reducing the overall supply of ground-related housing. Demand for ground-related housing continues to rise which supply cannot meet, resulting in increasing purchase prices for new units. Municipalities within the GGH have been required to adjust their planning accordingly to conform to the Growth Plan and the density targets have had a significant impact. MGP suggested that the Growth Plan is causing significant problems to permit municipalities from providing a greater supply of ground-related housing.

The literature review suggested this exact outcome. Past research has indicated that an increase in regulation increases the requirements for local planning processes, and this has a profound relationship with the supply and prices of housing. Malpezzi \& Bertaud suggested the Second Best Cost-Benefit Model had significant impacts on development. Implementing a uniform planning regulation has unique impacts for each individual location that is subject to that regulation. The Wharton Index showed that the extent of government involvement will have a significant impact on the overall planning process, such as the timing from development 
application to approval. Municipalities with above average political constraints to development had a tighter supply of ground-related housing, which was also less affordable. Finally, Glaeser et al suggested that by looking at the difference between construction and purchase price of a housing unit, we can see to what extent regulations are having an impact on added costs of housing.

Looking at York Region, the proposed density targets of the Growth Plan do not match the Region's own plans for growth. In order to match these targets, more spending will be required to provide the necessary infrastructure to support development. Seeing that demand is rising for ground-related housing, Malpezzi \& Bertaud (2001) and Cheshire et al (2015) were right to suggest we need to consider market demand. The Wharton Index (2007) suggests heavy government involvement slows down the planning process, which is indicative in York Region, and its ongoing delays of approving ROPAs 1, $2 \& 3^{17}$. The current structure of future development in York Region, through its WMP, TMP and OP allows for a certain amount of growth in designated greenfield areas. The proposed new density targets will cause significant changes to the Region's core policies and significantly increase unit growth in greenfield areas in order to reach Provincial targets.

The Proposed Growth Plan is deemed to have a greater negative impact on the planning process, especially if most municipalites, including within York Region, required the last 10 years, to transition their respective development to match the Province's original policy. It does not seem there will be a switch to increase the supply of ground-related housing any time soon for

\footnotetext{
${ }^{17}$ Crucial greenfield land to provide more ground-related housing units
} 
York Region or the GGH as a whole. The case study method should be completed for the remaining upper tier and single tier municipalities within the GGH. This will effectively illustrate to the Province that a one-size-fits-all policy for the region as a whole is a misrepresentation of the strategic priorities for each unique municipality, and directly constricting the supply of ground-related housing.

\subsection{Next Steps}

Based on the findings from the literature review, York Region documents, and consultation with municipal staff and developers, some suggestions can be made on improving the planning process for the GGH, specifically to allow for ground-related housing development in York Region while also maintaining continuity with its adjacent growing regions (McDonald \& McMillen, 2003). This section will go through the various recommendations, in order of priority to implement them. The four recommendations being made are:

\section{1) Reduce the target of 80 people and jobs per hectare in designated greenfield areas \\ 2) Reduce the time lag of development (from application submission to approval)}

\section{3) Watch market demand}

\section{4) Transition to remove a one-size-fits-all policy}

There is a loss of balance between the Province's proposed requirements and the response by both municipalities and developers. These recommendations can assist with Provincial interest to create effective land use policies related to growth and urban containment.

\subsubsection{Reduce the target of 80 People and Jobs per hectare in Designated Greenfield Areas}

Either the density target should be decreased, or the Growth Plan should remove the requirement that the average of all greenfield areas is to be 80 people and jobs per hectare. Otherwise, new 
greenfield development in certain municipalities will have to build at much higher densities to meet this specific average. This has been repeatedly outlined in documents such as the Mayors and Chairs Summit Report, and the Ontario Home Builders' Association's (OHBA) submission to the province on proposed revisions (2016). Until ROPA's 1, 2, and 3 are approved, York Region has limited space for greenfield development. As outlined by the Growth Plan, the average is to be met across the total designated greenfield area of the upper tier or single tier municipality. Shifting densities to other lower tier municipalities in York Region to accommodate for lower density development would be difficult to achieve and would require significant service improvements to areas that are on the urban fringe, or are adjacent to the Greenbelt or Oak Ridges Moraine. Markham, as shown in the map below, is one example of the location of remaining designated greenfield land. With the exception of one area just north of Unionville, the remaining land is adjacent to the Greenbelt or Oak Ridges Moraine. 


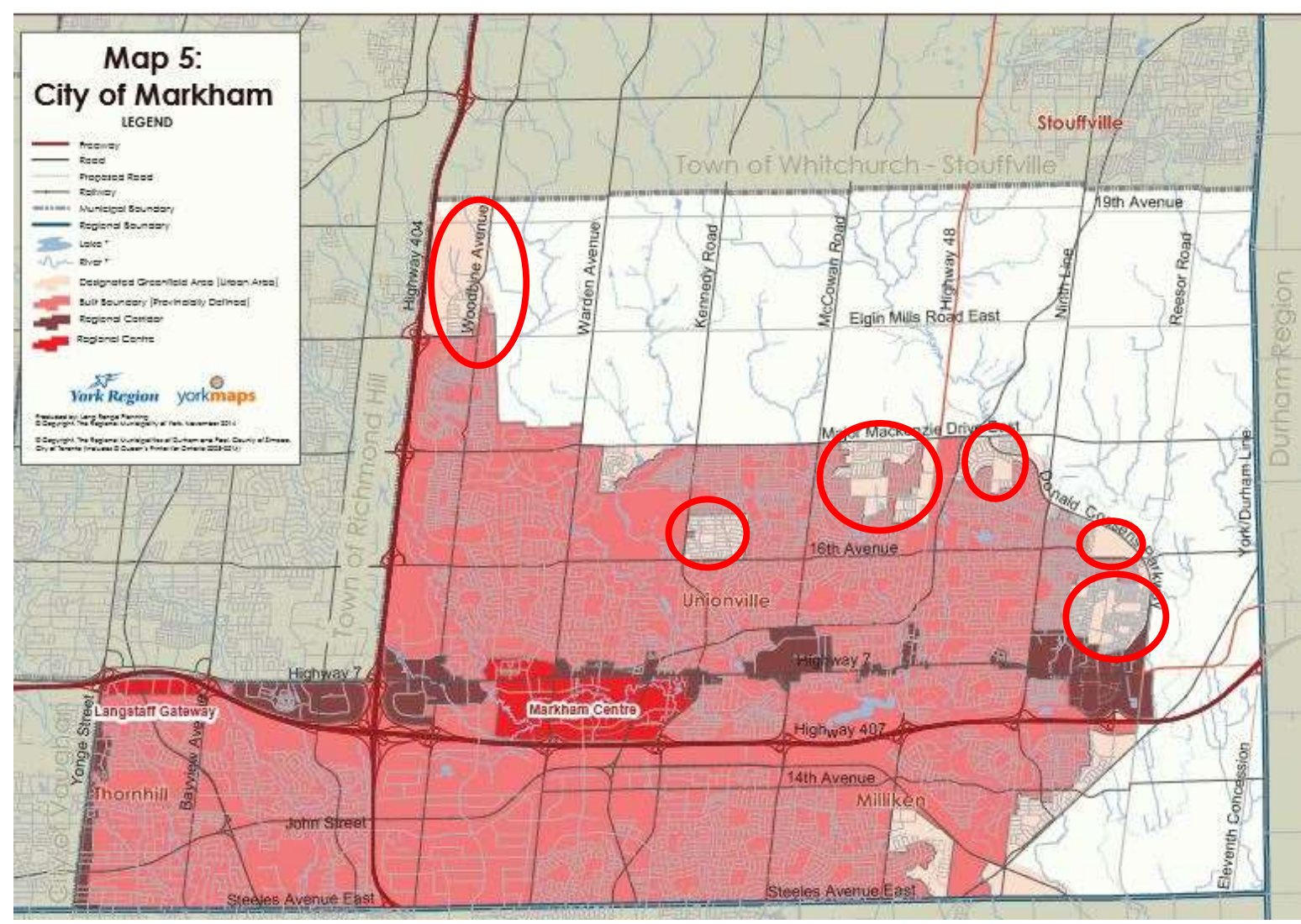

Figure 6: This map shows the remaining designated Greenfield areas for Markham. Portions of these lands contain draft approved plans of subdivisions that will have a density of less than the proposed 80 target. The remaining land, in white, is protected by the Greenbelt Plan and Oak Ridges Moraine Conservation Plan. Source: Regional Municipality of York, 2015.

\subsubsection{Reduce the time lag of development}

The Wharton Index (2007) outlined time lag as a significant contributor to understanding the extent of regulation. This refers to the time from development application submission, to approval of site plan or plan of subdivision. An immediate reaction to the state of development in York Region is finding a way to reduce the time lag in the planning process. The Growth Plan should provide assistance with future regional growth while also including a policy recommending to mark and reduce redundancies in the planning system. One such suggestion by the OHBA, was updating zoning by-laws across the GGH, to avoid wait times of amending when wishing to build at densities outlined by the Growth Plan itself. This would save a vast measure of time especially when developing along transit corridors, and overall help in reducing 
costs of development. Land can be purchased but still take years to develop due to the secondary plan process, the draft plan process, etc. This requires the owner or developer to pay fees associated with undeveloped land (i.e. taxes, interest carrying costs), and these costs add up over time. An additional element to improve, as mentioned by developers, is centralizing the planning system to ensure fewer departments are required to sign-off a planning file. An outlined checklist from each department in a municipality (e.g., environment, engineering, transportation, etc.) would ensure a more rigorous plan of subdivision or site plan application. This has been an ongoing issue over the years, and it is believed to be a top priority for the future of urban planning within the region.

\subsubsection{Watch market demand}

It is important to maintain a regional growth scenario moving forward. In addition, it is important to monitor housing market demand now, and in the future, in order to understand patterns of growth. Monitoring market demand means understanding where residents want to live and what housing types they are looking for. As Cheshire (2016) described, we can meet demand and build at lower densities while still reducing traffic congestion and remaining environmentally friendly. The key here is to improve transit access to ensure those living in low density communities on the urban fringe would not be required to drive everywhere they needed to go. The Province should place emphasis on increasing density along transit corridors - where the infrastructure is or will be coming in the next few years. In addition, the OHBA (2016) suggested in developing a transition in density for the built form of the GGH. This would mean building more of the missing middle-density between single-detached homes and high rise apartments and condominiums. Medium density can still be in the form of ground-related 
housing, such as developing rows of townhouses (OHBA, 2016). In order to assist with the current housing market, ensure Policy 1.4.1 of the Provincial Policy Statement is emphasized. This is not suggesting that all designated greenfield be developed with only single-detached homes. Rather supply a varied choice of housing within each neighbourhood. There also needs to be emphasis on maintaining a lower density built-form near the fringes of municipalities, especially near Greenbelt or Oak Ridges Moraine conservation areas.

If the Province wants to be the leader in regional growth, it is recommended they adopt a "Regional Spatial Strategy" project, something that was done in England. These strategy projects should not simply be based on how to efficiently house all residents, but how to strategically match living preferences. The importance here is to take into account housing forecasts based on demand and understand living behaviour of the residents. This was a similar suggestion made for the development of Washington DC and its adjacent counties (Urban Institute, 2016). This would require some organic growth dictated by the market, but controlled with land use policies. It is believed that doing so will mitigate market failure for a multitude of economic markers, including housing affordability. One such way to determine demand is looking at the value of land - based on development opportunity. If for a parcel of land, the value of developing for one use is significantly larger than the value for another use - the former use is considered more desirable. Planners can still control the use of land and the extent of growth, however the use for supplied land will reflect market demand (Cheshire et al, 2016). Moving back to the Growth Plan, once planners from the Province have a clear understanding of living preferences and demand, a clear decision can be made on strategizing growth in the GGH. The new Growth Plan would 
strategize housing development on a small regions basis - one which smaller regional markets can dictate development.

Based on the Washington DC case study, there are two methods to create greater housing choice while also increasing overall density. 1) Although not brought forth by developers, building accessory dwelling units would assist in increasing densities for low-rise communities, without repurposing them (Urban Institute, 2016). Using this option for York Region might help with meeting outlined density requirements if Recommendation 1 is adopted, such to reduce 80 people and jobs per hectare. 2) Offsetting any density requirements from designated greenfields to transit corridors would optimize the use of well serviced lands. One such example is Richmond Hill Centre at Yonge St. and Highway 7 in Richmond Hill. This area is serviced by both the Langstaff GO Train Station, the YRT VIVA Richmond Hill Centre Bus Terminal, and Highway 407. The area (refer to Appendix F) is mostly for commercial use, with some multiunit residences to the North, and ground-related units to the West. The proposal for Merrifield (in Washington DC) was converting the area into a mixed-use commercial residential town centre. The same could be feasible for Richmond Hill Centre. Both town centres are easily accessible to various modes of public transit, and yet the built form is mostly for commercial use. While these two options would increase smaller units in both ground-related and non-ground-related areas, it would provide a greater choice of living, i.e., for those who might wish to live in lower density but currently do not have the financial means to buy a ground-related home, or for those who prefer to live along a transit corridor. Adding more high-rise developments does increase the number of units available, but does not reflect offering housing choices or living environment choices. 


\subsubsection{Transition to Remove a One-Size-Fits-All Policy}

In terms of density, a one-size-fits-all policy implies each upper-tier or single-tier municipality, in the GGH, must incorporate the same density requirements, i.e., 80 people and jobs per hectare and 60 percent of development as intensification. Moving forward, the Growth Plan for the Greater Golden Horseshoe should remain a policy directing growth for the GGH, but it needs varying targets for each municipality. York Region has a fairly different urban structure than Peel, Halton, or Durham Regions. This has become recently apparent when upper and single tier municipalities were compared for meeting the intensification target. Figure 7, below, from Andrew Cohrs (2017), shows intensification decreasing beyond 2010 in some regions. It was suggested this is related to development of greenfield sites that were originally included in the Provinces calculations for the 2006 Growth Plan. Now that those sites have been developed, the actual proportion of intensification development has decreased.

\begin{tabular}{l|c|c}
\hline \multicolumn{1}{c|}{ Municipality } & $\begin{array}{c}2007-2010 \\
\text { 4-year average (\%) }\end{array}$ & $\begin{array}{c}\text { 2011-2014 } \\
\text { 4-year average (\%) }\end{array}$ \\
\hline City of Toronto & 100 & 100 \\
\hline Niagara Fregion & 64 & 51 \\
\hline Peel Region & 47 & 34 \\
\hline City of Hamilton & 48 & 30 \\
\hline Durham Region & 46 & 37 \\
\hline York Region & 46 & 52 \\
\hline Waterloo Region & 36 & 55 \\
\hline Halton Region & 33 & 35 \\
\hline
\end{tabular}

Figure 7: Current proportion of development that is Intensification. Note: Reprinted from Implementing the Growth Plan, by Nicola Crawhall and Associates, 2015

Region specific densities can allow upper tier municipalities to direct lower-tier municipalities' development more effectively. As described in the literature review, just as uppertier municipalities should have control over development within its region, so too the Province 
should maintain the Growth Plan to ensure connectivity of the GGH as a whole. One step in doing exactly that is implementing Metrolinx plans for transit development in the region.

The Growth Plan can set a precedent for passing regional planning policy. By working with each individual upper-tier or single-tier municipality in the GGH, the Province can more appropriately direct growth and avoid inappropriate density numbers for development. Consultation between the two levels of government in the form of workshops - where the Province and municipalities can have an understanding of respective growth outlooks, would cascade into more informed density targets. This would remove the one year response period after announcing the proposed amendments, such as what occurred in May, 2016. This can apply well to discussing ROPAs 1, 2 \& 3 in York Region. The direct consultation between the Province and Region would allow for flexibility in density requirements as York Region permits built boundary expansions in East Gwillimbury, Markham and Vaughan. An agreement deriving from discussion could be to continue the 80 people and jobs per hectare in already existing designated greenfield areas, but allow for significantly lower densities in these ROPA areas - to allow for an easy transition in density while entering the Greenbelt or Oak Ridges Moraine.

In regard to Malpezzi \& Bertaud (2001), a similar cost-benefit analysis can be applied to regional land use regulation. The Proposed Growth Plan has outlined new density structures for the municipalities in the GGH. Therefore, if a municipality will require a specific density structure that a) does not reflect the population size and b) does not reflect simple human behaviour of living - the costs may noticeably outweigh the benefits. Developers will be required to build more condominium-style buildings - whereas the preferred housing type is ground-related. In addition the behavioural or demand shift will not occur. Going back to the scenario on roads 
requirements - the regulation increased construction costs of developments. In the case of the Growth Plan, developers are now limited to how many ground-related houses they can build, although the limitation is not reflective of the population's needs. It seems to be that as a general rule, if the regulation is too generally applied, it is likely the costs will begin to outweigh benefits. The Growth Plan needs to be amended accordingly to respond to behavioural patterns in addition to covering the Provinces agenda. This could mean applying city-specific densities (i.e. a case-bycase structure similar to their first method). Alternatively, multiple harmonized density structures could be formed. Vaughan, Markham, and Richmond Hill could have similar density requirements, whereas more peripheral municipalities, such as Aurora, East Gwillimbury, and King can have an alternative density requirement for greenfield areas that attributes to their smaller scale. 
Appendices

Appendix A: Data from Malone Given Parsons Ltd.

\section{Greenfield Land Remaining}
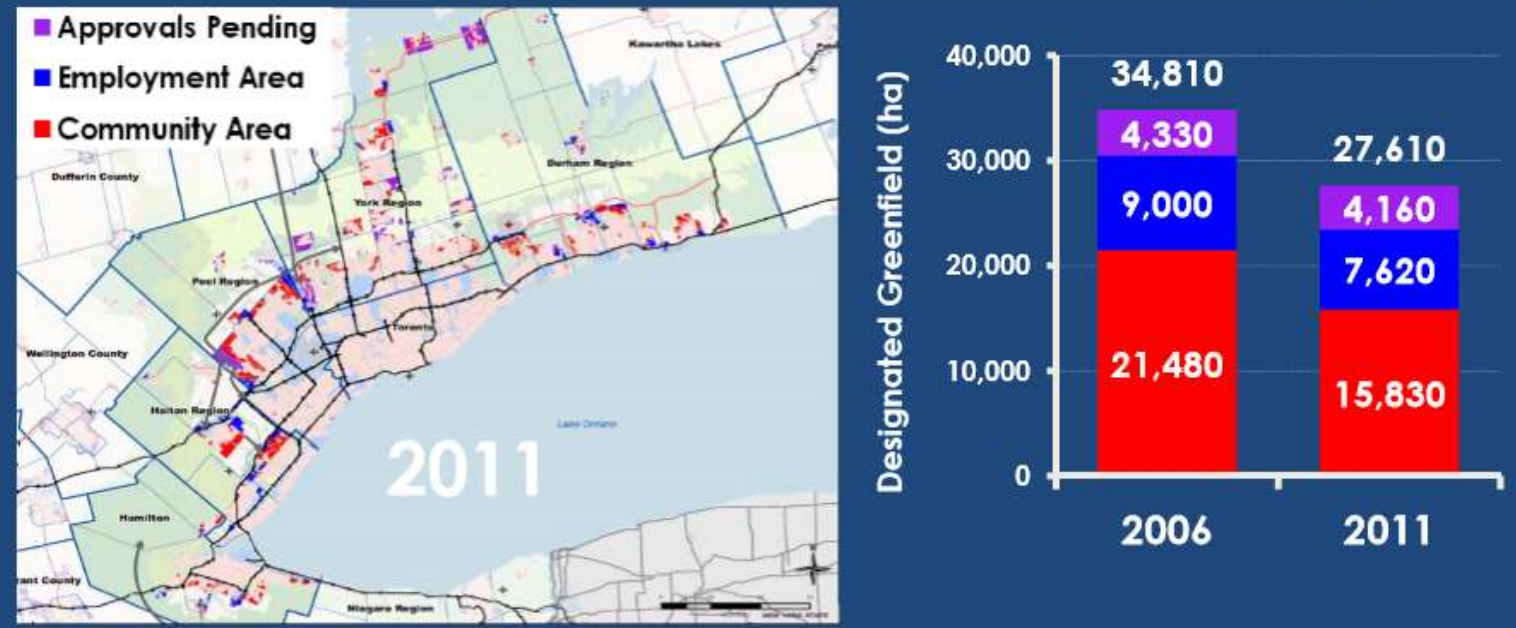

MALONE GIVEN PARSONS LTD. 140 RENFREW DR. MARKHAM, ONTARIO

(905) 513-0170 I WWW.MGP.CA

\section{GTAH Housing Need vs Density Targets}

Residential Growth Historical Trend vs. Regional Implementation Unit Mix, 2006-2031

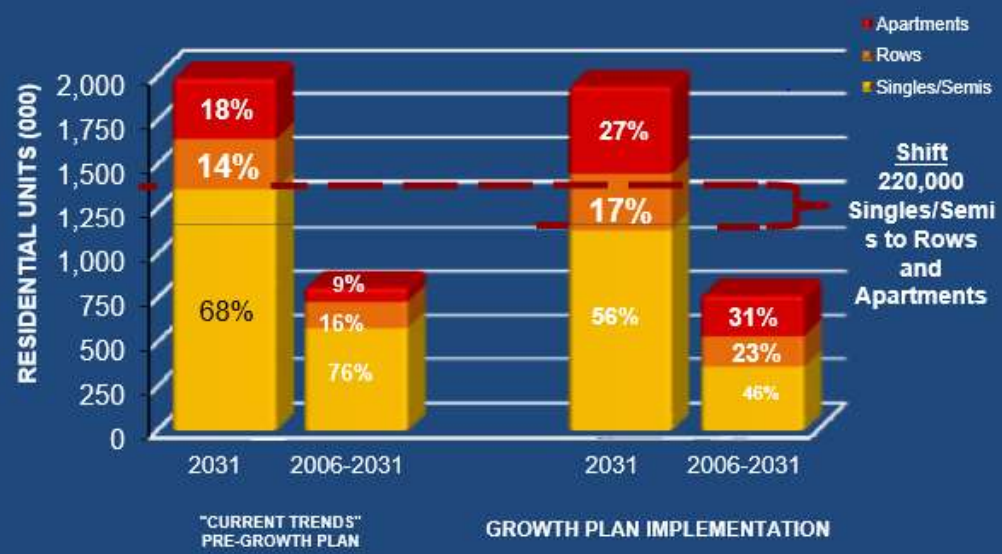

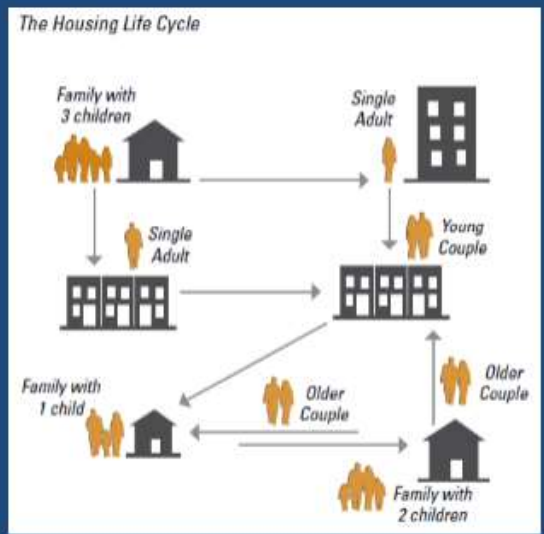

MALONE GIVEN PARSONS LTD. 140 RENFREW DR. MARKHAM, ONTARIO (905) 513-0170 | WWW.MGP.CA

Showing the change in distribution of housing types in the GTA (Malone Given Parsons Ltd., 2015) 
Appendix B - Altus Construction Costs Table (From 2006-2016)

\begin{tabular}{|l|c|c|c|}
\hline \multicolumn{4}{|c|}{ Greater Toronto Area Construction Cost (Per Square Foot) } \\
\hline Housing Type/Year & $\begin{array}{c}\text { Single-Family (Basic } \\
- \text { High Quality) }\end{array}$ & Row Townhouses & Stack Townhouses \\
\hline $\mathbf{2 0 0 6}$ & $\$ 62-\$ 191$ & $\$ 78-\$ 95$ & $\$ 96-\$ 138$ \\
\hline $\mathbf{2 0 0 7}$ & $\$ 67-\$ 250$ & $\$ 85-\$ 105$ & $\$ 105-\$ 150$ \\
\hline $\mathbf{2 0 0 8}$ & $\$ 81-\$ 338$ & $\$ 96-\$ 121$ & $\$ 119-\$ 173$ \\
\hline $\mathbf{2 0 0 9}$ & $\$ 80-\$ 325$ & $\$ 85-\$ 115$ & $\$ 110-\$ 160$ \\
\hline $\mathbf{2 0 1 0}$ & $\$ 80-\$ 350$ & $\$ 80-\$ 110$ & $\$ 110-\$ 145$ \\
\hline $\mathbf{2 0 1 1}$ & $\$ 85-\$ 350$ & $\$ 90-\$ 115$ & $\$ 115-\$ 150$ \\
\hline $\mathbf{2 0 1 2}$ & $\$ 75-\$ 350$ & $\$ 85-\$ 115$ & $\$ 115-\$ 150$ \\
\hline $\mathbf{2 0 1 3}$ & $\$ 80-\$ 375$ & $\$ 90-\$ 120$ & $\$ 120-\$ 155$ \\
\hline $\mathbf{2 0 1 4}$ & $\$ 80-\$ 390$ & $\$ 90-\$ 120$ & $\$ 115-\$ 155$ \\
\hline $\mathbf{2 0 1 5}$ & $\$ 90-\$ 390$ & $\$ 75-\$ 120$ & $\$ 115-\$ 155$ \\
\hline $\mathbf{2 0 1 6}$ & $\$ 90-\$ 180$ & $\$ 75-\$ 120$ & $\$ 115-\$ 155$ \\
\hline
\end{tabular}

Source: Altus Construction Cost Guides (2006-2016) 
Appendix C - Schedule of Water and Wastewater Servicing Improvements

\begin{tabular}{|c|c|c|c|c|}
\hline \multicolumn{5}{|c|}{ Water Servicing Improvement Timeline (Vaughan, Richmond Hill, and Markham) } \\
\hline Municipality & Project & Purpose of Project & $\begin{array}{l}\text { Year Range to } \\
\text { Completion }\end{array}$ & EA Status \\
\hline \multirow[t]{2}{*}{ Markham } & $\begin{array}{c}\text { Richmond } \\
\text { Hill/Langstaff } \\
\text { Gateway Water } \\
\text { Servicing }\end{array}$ & $\begin{array}{l}\text { To support the } \\
\text { proposed urban } \\
\text { growth center } \\
\text { (also applicable to } \\
\text { Richmond Hill as } \\
\text { Described below) } \\
\end{array}$ & $2021-2025$ & EA Complete \\
\hline & $\begin{array}{l}\text { North Markham } \\
\text { Water Servicing }\end{array}$ & $\begin{array}{l}\text { To support urban } \\
\text { expansion north of } \\
\text { Elgin Mills Road in } \\
\text { Markham }\end{array}$ & $2031-2035$ & $\begin{array}{c}\text { EA Screening } \\
\text { Process Required }\end{array}$ \\
\hline $\begin{array}{l}\text { Richmond } \\
\text { Hill }\end{array}$ & $\begin{array}{c}\text { Richmond } \\
\text { Hill/Langstaff } \\
\text { Gateway Water } \\
\text { Servicing }\end{array}$ & $\begin{array}{l}\text { To support the } \\
\text { proposed urban } \\
\text { growth centre }\end{array}$ & $2021-2025$ & EA Complete \\
\hline \multirow{5}{*}{ Vaughan } & $\begin{array}{l}\text { Maple Pumping } \\
\text { District } 8 \text { Station } \\
\text { Pump Addition }\end{array}$ & $\begin{array}{l}\text { To Support } \\
\text { development in } \\
\text { northeast } \\
\text { Vaughan }\end{array}$ & $2016-2020$ & EA Not Required \\
\hline & $\begin{array}{l}\text { South Maple } \\
\text { Reservoir } \\
\text { Upgrade }\end{array}$ & $\begin{array}{l}\text { Depth adjustment } \\
\text { to minimize } \\
\text { unusable storage } \\
\text { below }\end{array}$ & $2016-2020$ & EA Not Required \\
\hline & $\begin{array}{c}\text { West Vaughan } \\
\text { Water Servicing - } \\
\text { Phase } 1\end{array}$ & $\begin{array}{l}\text { Improve water } \\
\text { service in } \\
\text { Woodbridge Area }\end{array}$ & $2016-2020$ & EA Not Required \\
\hline & $\begin{array}{c}\text { Pumping District } 6 \\
\text { Feedermain } \\
\text { System Pressure } \\
\text { Improvements }\end{array}$ & $\begin{array}{l}\text { To increase supply } \\
\text { of water from Peel } \\
\text { Region to York } \\
\text { Region }\end{array}$ & $2026-2030$ & EA Not Required \\
\hline & $\begin{array}{c}\text { Northeast } \\
\text { Vaughan Water } \\
\text { Servicing }\end{array}$ & $\begin{array}{l}\text { To support urban } \\
\text { expansion in } \\
\text { northeast } \\
\text { Vaughan }\end{array}$ & $2026-2030$ & EA in Progress \\
\hline
\end{tabular}

Source: Water \& Wastewater Master Plan, 2015 


\begin{tabular}{|c|c|c|c|c|}
\hline \multicolumn{5}{|c|}{ Wastewater Servicing Improvement Timeline (Vaughan, Richmond Hill, and Markham) } \\
\hline Municipality & Project & Description & $\begin{array}{l}\text { Year Range of } \\
\text { Completion }\end{array}$ & EA Status \\
\hline \multirow[b]{2}{*}{ Markham } & $\begin{array}{c}\text { North Markham } \\
\text { Sewer }\end{array}$ & $\begin{array}{l}\text { To service future } \\
\text { growth in North } \\
\text { Markham }\end{array}$ & $2031-2035$ & $\begin{array}{l}\text { EA Screening } \\
\text { Process } \\
\text { Required }\end{array}$ \\
\hline & $\begin{array}{c}\text { Richmond } \\
\text { Hill/Langstaff } \\
\text { Gateway } \\
\text { Wastewater } \\
\text { Servicing } \\
\end{array}$ & $\begin{array}{l}\text { To support the } \\
\text { Urban Growth } \\
\text { Centre, connect } \\
\text { to the Richmond } \\
\text { Hill Collector }\end{array}$ & $2021-2025$ & EA Complete \\
\hline \multirow[b]{2}{*}{ Richmond Hill } & $\begin{array}{l}\text { Richmond } \\
\text { Hill/Langstaff } \\
\text { Gateway } \\
\text { Wastewater } \\
\text { Servicing }\end{array}$ & $\begin{array}{l}\text { To support the } \\
\text { Urban Growth } \\
\text { Centre, connect } \\
\text { to the Richmond } \\
\text { Hill Collector }\end{array}$ & $2021-2025$ & EA Complete \\
\hline & $\begin{array}{l}\text { Yong Street } \\
\text { Sewer Twinning }\end{array}$ & $\begin{array}{l}\text { To support } \\
\text { growth and } \\
\text { increase flow } \\
\text { from Aurora, } \\
\text { Newmarket and } \\
\text { Richmond Hill. }\end{array}$ & $2031-2035$ & $\begin{array}{l}\text { EA Screening } \\
\text { Process } \\
\text { Required }\end{array}$ \\
\hline \multirow[t]{2}{*}{ Vaughan } & $\begin{array}{l}\text { Northeast } \\
\text { Vaughan } \\
\text { Wastewater } \\
\text { Servicing }\end{array}$ & $\begin{array}{l}\text { To support } \\
\text { development in } \\
\text { northeast } \\
\text { Vaughan - } \\
\text { connect } \\
\text { increase flow to } \\
\text { Jane Rutherford } \\
\text { Sewer }\end{array}$ & $2026-2030$ & EA in Progress \\
\hline & $\begin{array}{c}\text { West Vaughan } \\
\text { Sewage } \\
\text { Servicing Phase } \\
1\end{array}$ & $\begin{array}{l}\text { To service } \\
\text { development in } \\
\text { northwest } \\
\text { Vaughan } \\
\text { towards } \\
\text { Kleinburg }\end{array}$ & $2026-2030$ & EA Complete \\
\hline
\end{tabular}

Source: Water \& Wastewater Master Plan, 2015 
Appendix D -York Region Water \& Wastewater Servicing Maps

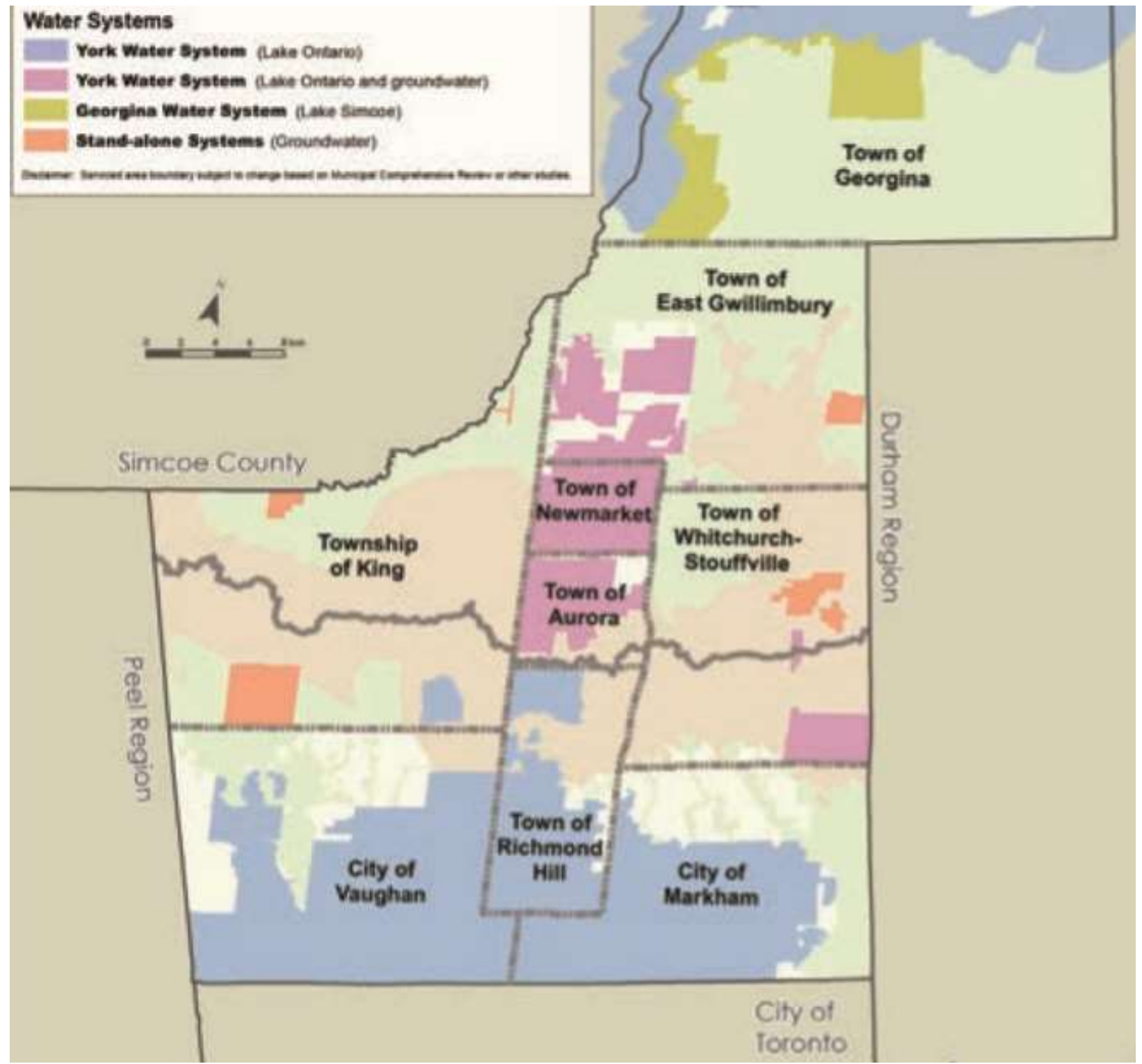

Regional Municipality of York Water Systems, Source: Regional Municipality of York, 2016c 


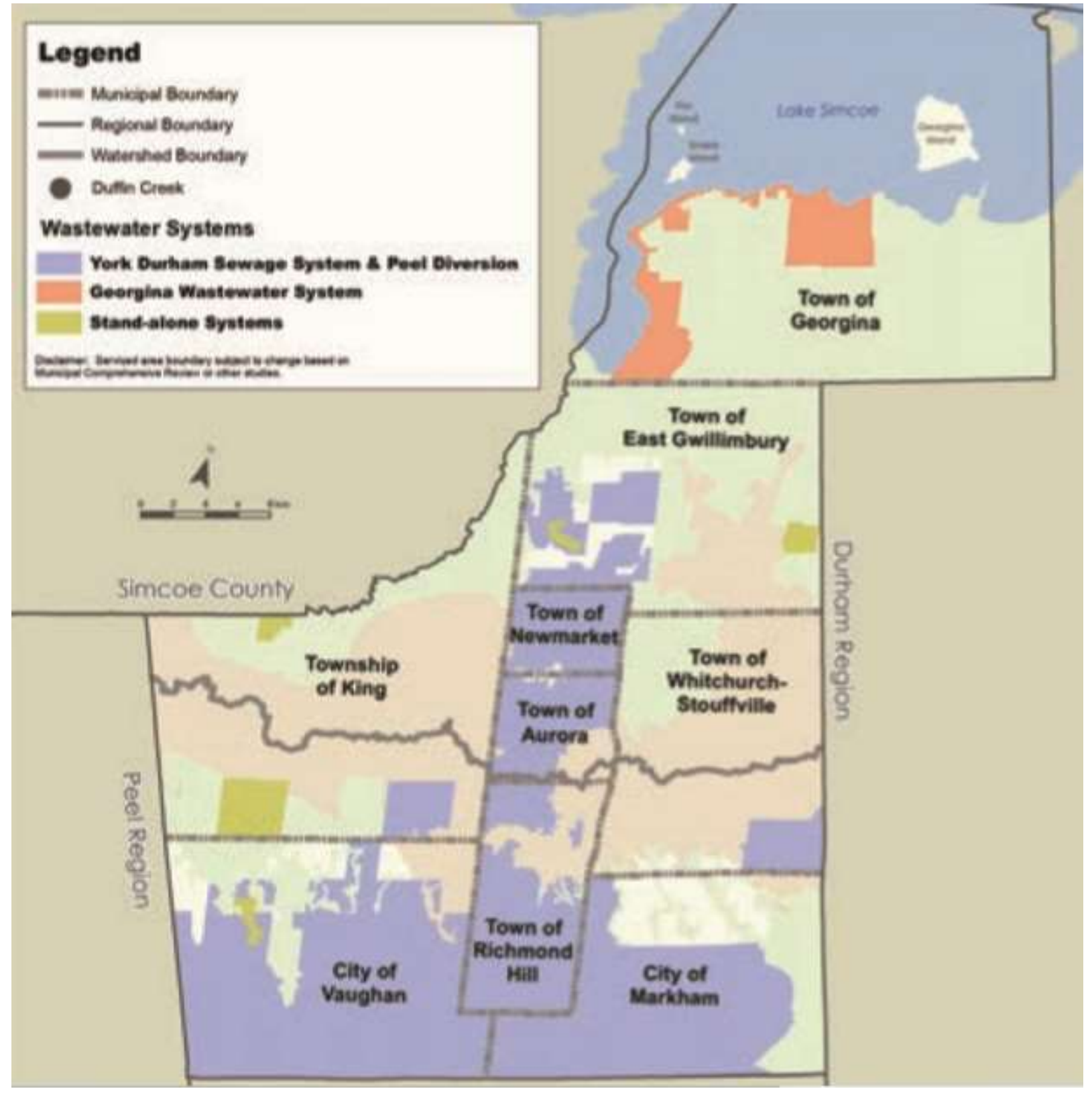

Regional Municipality of York Wastewater System, Source: Regional Municipality of York, 2016c 


\section{Appendix E: York Region Road Class System}

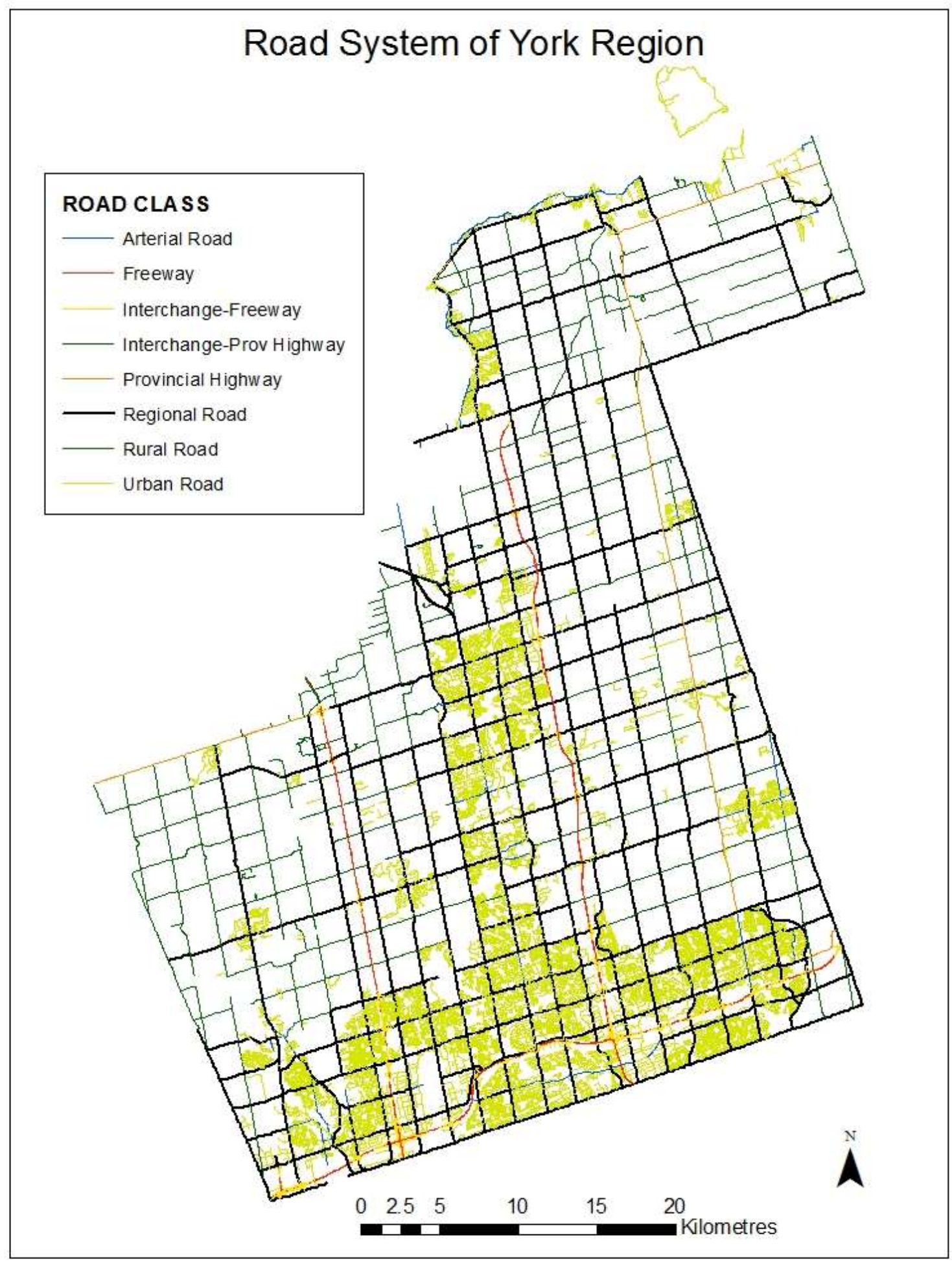

Road open data from the Regional Municipality of York, 2014 


\section{Appendix F - Population Growth in York Region}

Table 3.1 - Residential Population Forecast for 2041

\begin{tabular}{|l|c|c|c|c|}
\hline \multicolumn{1}{|c|}{$\begin{array}{c}\text { Local } \\
\text { Municipality }\end{array}$} & $\begin{array}{c}\text { Current } \\
\text { Population }\end{array}$ & $\begin{array}{c}\text { Forecast } \\
\text { Population } \\
(\mathbf{2 0 4 1 )}\end{array}$ & $\begin{array}{c}\text { Percent } \\
\text { Change } \\
(\%)\end{array}$ & $\begin{array}{c}\text { Portion of } \\
\text { Regional } \\
\text { Growth (\%) }\end{array}$ \\
\hline Aurora & 56,600 & 79,000 & $39.6 \%$ & $3.5 \%$ \\
\hline East Gwillimbury & 24,400 & 118,700 & $386.5 \%$ & $14.9 \%$ \\
\hline Georgina & 47,300 & 71,300 & $50.7 \%$ & $3.8 \%$ \\
\hline King & 24,400 & 37,900 & $55.3 \%$ & $2.1 \%$ \\
\hline Markham & 346,900 & 535,100 & $54.3 \%$ & $29.7 \%$ \\
\hline Newmarket & 85,900 & 108,200 & $26.0 \%$ & $3.5 \%$ \\
\hline Richmond Hill & 205,100 & 277,900 & $35.5 \%$ & $11.5 \%$ \\
\hline Vaughan & 320,800 & 497,400 & $55.0 \%$ & $27.9 \%$ \\
\hline Whitchurch- & 44,900 & 64,500 & $43.7 \%$ & $3.1 \%$ \\
\hline Stouffille & & & & $\mathbf{1 0 0} \%$ \\
\hline York Region & $\mathbf{1 , 1 5 6 , 2 0 0}$ & $\mathbf{1 , 7 9 0 , 0 0 0}$ & $\mathbf{5 4 . 8 \%}$ & \\
\hline
\end{tabular}

Note: Current population as of mid-year 2015

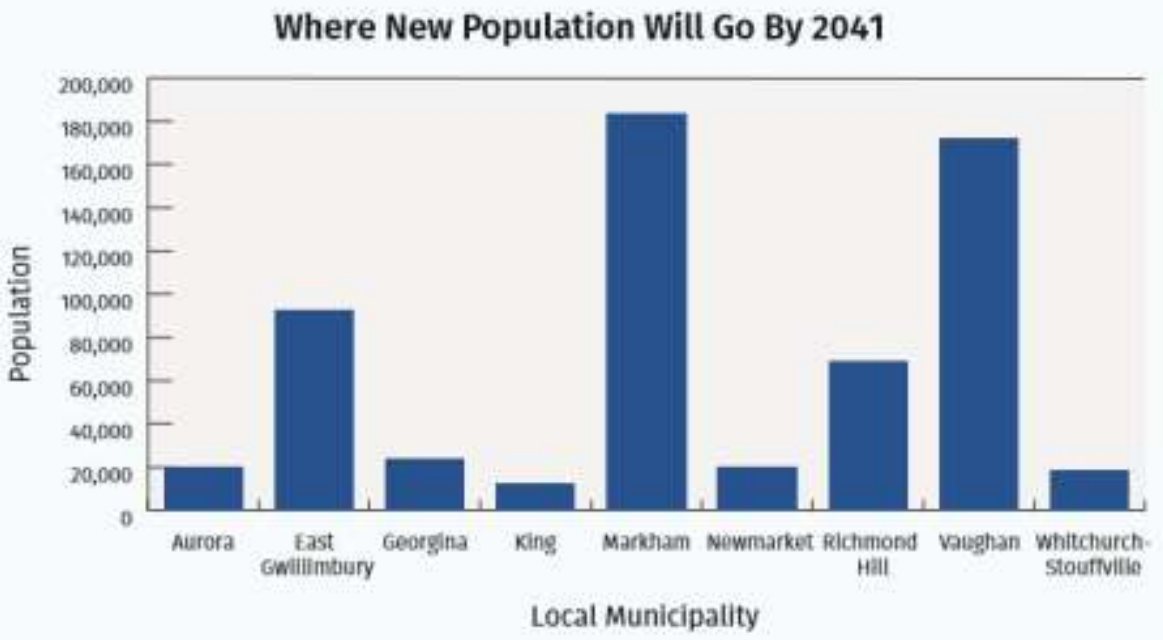

Population growth by lower tier municipality, Source: Regional Municipality of York, 2016c 
Appendix G - Map of York Region, Including ROPAs 1, 2 \& 3

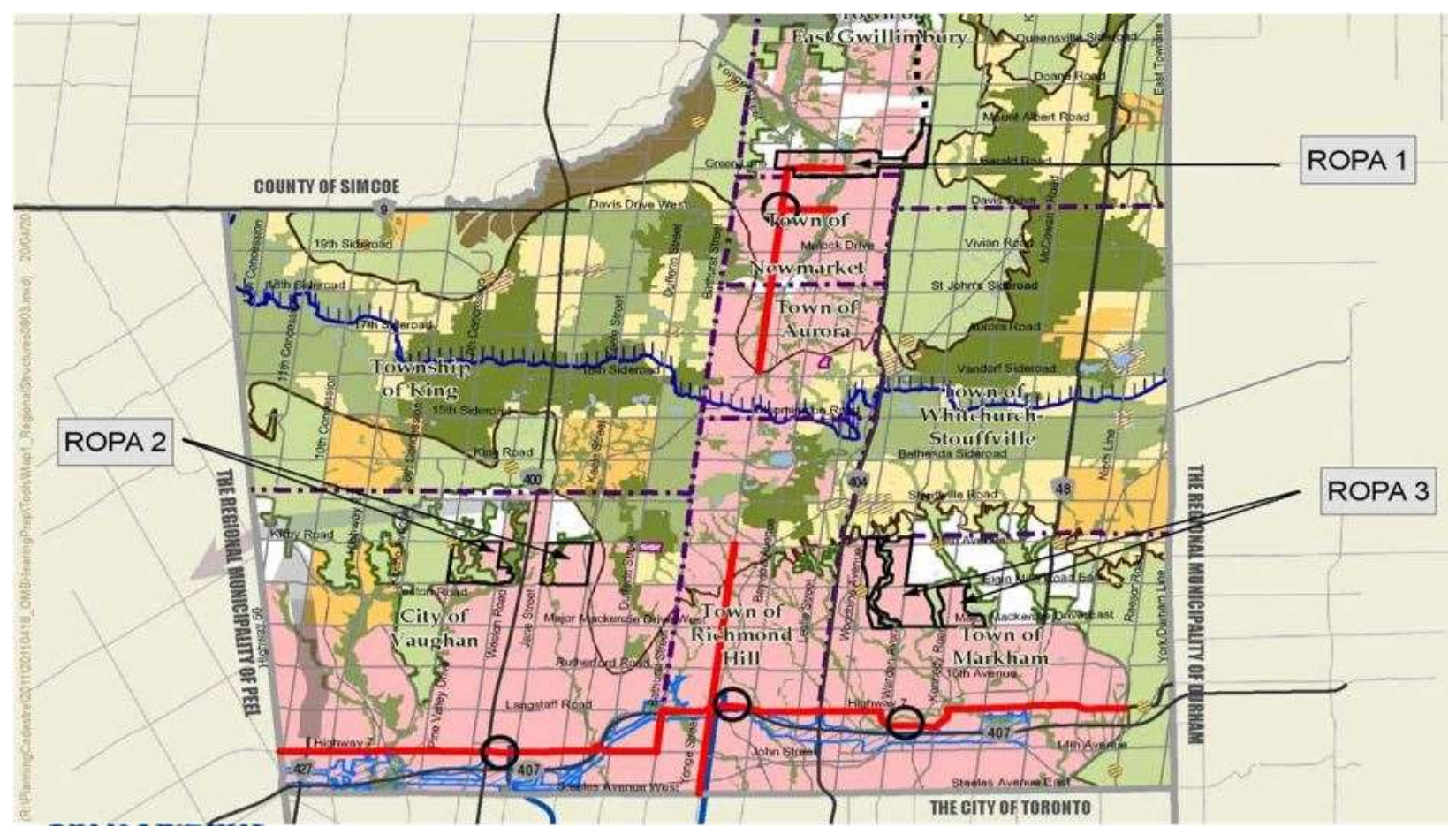

Regional Official Plan Amendments 1, 2 \& 3, Source: Planning and Economic Development Committee, 2012

Appendix $\mathrm{H}$ - Richmond Hill Centre

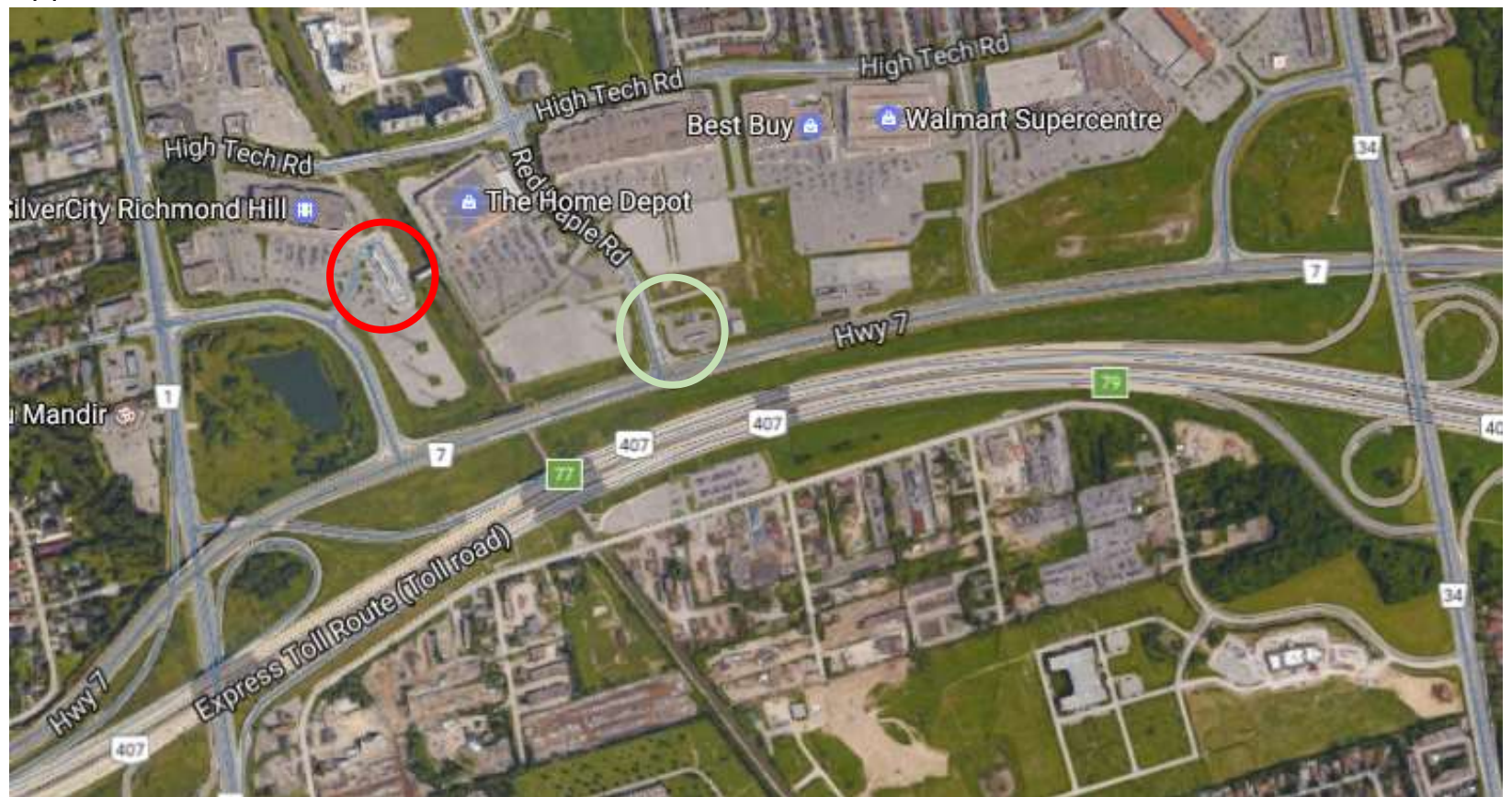

The red circle is the VIVA bus terminal and the pale green circle is the Langstaff GO Train Station, Source: Google Maps, 2016 


\section{$\underline{\text { References }}$}

(2016). MLS Home Price Index. The Canadian Real Estate Association. Retrieved from: http://www.crea.ca/housing-market-stats/mls-home-price-index/hpi-tool/

Altus Group (2016). Altus Construction Cost Guide (2006-2016). Retrieved from http://www.altusgroup.com/services/cost-guide/

Amborski, D. (2016). Finance and Local Governance lecture: November 10, 2016. Ryerson University: School of Urban and Regional Planning.

Amborski, D. \& Clayton, F. (2016). The Need to Make Housing Affordability a Primary Goal in Regional Planning for the Greater Golden Horseshoe. Centre for Urban Research and Land Development, Ryerson University. Retrieved from: http://www.ryerson.ca/content/dam/cur/pdfs/policycommentaries/CUR\%20Policy\%20 Report\%20_\%20Response\%20to\%20Proposed\%20Growth\%20Plan_2016.pdf

Bank of Canada. (2017). Selected Historial Interest Rates. Retrieved from

http://www.bankofcanada.ca/rates/interest-rates/selected-historical-interest-rates/

Burda, C. (2013). Priced Out: Understanding the factors affecting home prices in the GTA. RBC-Pembina Location Matters Series. Retrieved from https://www.pembina.org/reports/priced-out.pdf

Blumenthal, P., McGinty, R., \& Pendall, R. (2016). Strategies for Increasing Housing Supply in High-Cost Ciies: DC Case Study. Urban Institute

Canadian Mortgage and Housing Corporation (2017). Housing Market Information Portal. Retrieved from https://www03.cmhcschl.gc.ca/hmiportal/en/\#TableMapChart/2270/3/Toronto

Cheshire, P., Nathan, M., \& Overman, H. (2015). Urban Economics and Urban Policy: Challening Conventional Wisdom. Edward Elgar Publishing.

Cheshire, P. (2016). Economics and Land Use Planning in the Greater Golden Horseshoe. Centre for Urban Research and Land Development. Ryerson University.

Cohrs, A. (2017). Revisiting the Growth Plan, Unworkable Goals. Novae Res Urbis.

Glaeser, E., Gyourko, J., \& Saks, R. (2005). Why is Manhattan So Expensive? Regulation and the Rise in Housing Prices. The Journal of Law and Economics, 48, 331-369.

Google Maps. (2016). Richmond Hill Centre. Retrieved from https://www.google.ca/maps/place/ Richmond+Hill+Centre/@43.8401624,79.4277422,17z/data=!3m1!4b1!4m5!3m4!1s0x882b2b 82 78bb1bfd:0xfd952f44c1112ff7!8m2!3d43.8401624!4d-79.4255535

Government of Ontario. (1990). Planning Act. 
Government of Ontario. (2016). Proposed Growth Plan for the Greater Golden Horseshoe. Retrieved from https://www.placestogrow.ca/index.php?option=com_content \&task=view\&id=420\&Itemid $=12$

Green, K., Filipowicz, J., Lafleur, S., \& Herzog, I. (2016). The Impact of Land-Use Regulation on Housing Supply in Canada. Fraser Institute.

Green, K. P., Herzog, I., \& Filipowicz, J. (2015). Residential Land-Use Regulation in Ontario's Greater Golden Horseshoe. Fraser Institute.

Gyourko, J., Saiz, A., \& Summers, A. (2007). A New Measure of the Local Regulatory Environment for Housing Markets: The Wharton Residential Land Use Regulatory Index.

Huang, H. (2012). Residential land use regulation and the US housing price cycle between 2000 and 2009. Journal of Urban Economics, 71(1). Retrieved from http://resolver.scholarsportal.info/resolve/00941190/v71i0001/93_rluratpcb2a2.xml

Kim, J., Deal, B., \& Chakraborty, B. (2013). Parsing density changes: an outcome-oriented growth management policy analysis. Journal of Housing and the Built Environment, 28(3).

Kim, J. H. (2011). Linking Land Use Planning and Regulation to Economic Development: A Literature Review. Journal of Planning Literature, 26(1), 35-47.

Luger, M., \& Temkin, K. (2000). Red Tape and Housing Costs. New Brunswick, NJ: Center for Urban Policy Research.

Malone Given Parsons LTD. (2015a). Discussion Brief: The Risks Attached to an Intensification Target Greater than $40 \%$.

Malone Given Parsons LTD. (2015b). Making the Growth Plan Relevant to Current Economic Conditions.

Malpezzi, S., \& Bertaud, A. (2001). Measuring the Costs and Benefits of Urban Land Use Regulation: A Simple Model with an Application to Malaysia. Journal of Housing Economics, 10, 393-418. http://doi.org/10.1006

McCallion, H. (2016). Greater Toronto \& Hamilton Area (GTHA) Mayors and Chairs Summit.

McDonald, J., \& McMillen, D. (2003). Costs and Benefits of Land Use Regulations: A Theoretical Survey. Journal of Real Estate Literature, 11(2), 157-175.

Metrolinx. (2016). Discussion Paper for the Next Regional Transportation Plan, Greater Toronto and Hamilton Area.

Nelson, A., \& Dawkins, C. (2004). Urban Containment in the United States: History, Models, and Techniques for Regional and Metropolitan Growth Management. Chicago, Il: American Planning Association. 
New Zealand Productivity Commission. (2016). Better Urban Planning.

Nicola Crawhall and Associates. (2015). Implementing the Growth Plan. Retrieved from http://www.rpco.ca/files/Implementing_the_Growth_Plan_-_May_19.pdf

Ontario Home Builders' Association. (2016). Co-ordinated Review, Proposed Growth Plan for the Greater Golden Horseshoe.

Ontario Ministry of Municipal Affairs. (2002). Oak Ridges Moraine Conservation Plan.

Ontario Ministry of Municipal Affairs. (2005a). Greenbelt Act. Retrieved from http://www.mah.gov.on.ca/Page195.aspx

Ontario Ministry of Municipal Affairs. (2005b). Niagara Escarpment Plan. Retrieved from https://www.ontario.ca/document/niagara-escarpment-plan

Planning and Economic Development Committee. (2006). York Region Vacant Unit Supply Inventory. Regional Municipality of York.

Planning and Economic Development Committee. (2010). Regional Council Meeting. York Region Official Plan. Regional Municipality of York.

Planning and Economic Development Committee. (2012). Ground-Related Housing Demand/Supply Analysis. Regional Municipality of York.

Planning and Economic Development Committee. (2016). Draft Provincial Plan Amendments Regional Submission. Regional Mu6nicipality of York.

Regional Municiaplity of York. (2015). Residential Unit Supply Inventory. Committee of the Whole March 26, 2015.

Regional Municipality of York. (2016a). York Region Growth and Development Review 2015.

Regional Municipality of York. (2016b). Transportation Master Plan.

Regional Municipality of York. (2016c). Water and Wastewater Master Plan.

Road System of York Region [map]. Scale 1:309,784. Data Layers: York Region Open Data: Regional Roads [computer files]. Using ArcGIS for Desktop Advanced [GIS]. Version 10.5. Redlands, CA: Esri, 2015

Toronto Real Estate Board. (2017). TREB Market Watch 2012-2016.

Urbanation. (2017). GTA Condo Rents Up 12\% to Nearly $\$ 2,000$. Retrieved from https://www.urbanation.ca/blog/2017-01/gta-condo-rents-12-nearly-2000

Wollen, P., \& Kerr, J. (2002). Erosion of Cities or Attrition of Automobiles. In Autopia. 